\title{
Retinoic Acid Signaling Mediates Hair Cell Regeneration by Repressing p27kip and sox2 in Supporting Cells
}

\author{
Davide Rubbini, ${ }^{*}$ Àlex Robert-Moreno, ${ }^{\star}$ Esteban Hoijman, and Berta Alsina \\ Laboratory of Developmental Biology, Departament de Ciències Experimentals i de la Salut, Universitat Pompeu Fabra, Parc de Recerca Biomèdica de \\ Barcelona, 08003 Barcelona, Spain
}

During development, otic sensory progenitors give rise to hair cells and supporting cells. In mammalian adults, differentiated and quiescent sensory cells are unable to generate new hair cells when these are lost due to various insults, leading to irreversible hearing loss. Retinoic acid (RA) has strong regenerative capacity in several organs, but its role in hair cell regeneration is unknown. Here, we use genetic and pharmacological inhibition to show that the RA pathway is required for hair cell regeneration in zebrafish. When regeneration is induced by laser ablation in the inner ear or by neomycin treatment in the lateral line, we observe rapid activation of several components of the RA pathway, with dynamics that position RA signaling upstream of other signaling pathways. We demonstrate that blockade of the RA pathway impairs cell proliferation of supporting cells in the inner ear and lateral line. Moreover, in neuromast, RA pathway regulates the transcription of $p 27^{k i p}$ and sox 2 in supporting cells but not $f g f 3$. Finally, genetic cell-lineage tracing using Kaede photoconversion demonstrates that de novo hair cells derive from FGF-active supporting cells. Our findings reveal that RA has a pivotal role in zebrafish hair cell regeneration by inducing supporting cell proliferation, and shed light on the underlying transcriptional mechanisms involved. This signaling pathway might be a promising approach for hearing recovery.

Key words: hair cells; inner ear; lateral line; regeneration; retinoic acid; zebrafish

Significance Statement

Hair cells are the specialized mechanosensory cells of the inner ear that capture auditory and balance sensory input. Hair cells die after acoustic trauma, ototoxic drugs or aging diseases, leading to progressive hearing loss. Mammals, in contrast to zebrafish, lack the ability to regenerate hair cells. Here, we find that retinoic acid (RA) pathway is required for hair cell regeneration in vivo in the zebrafish inner ear and lateral line. RA pathway is activated very early upon hair cell loss, promotes cell proliferation of progenitor cells, and regulates two key genes, $p 27^{k i p}$ and sox2. Our results position RA as an essential signal for hair cell regeneration with relevance in future regenerative strategies in mammals.

\section{Introduction}

Cellular aging, exposure to loud noise or ototoxic drugs leads to hair cell damage and subsequent hearing loss. In adult mammals,

Received March 20, 2015; revised Sept. 28, 2015; accepted 0ct. 3, 2015.

Author contributions:D.R., A.R.-M., and B.A. designed research;D.R., A.R.-M., and E.H. performed research;D.R., A.R.-M., and B.A. analyzed data; D.R. and B.A. wrote the paper.

This work was supported by Fundación Areces XVI CN Grants BFU2011-27006 and BFU2014-55738 REDT to B.A. A.R.-M. was supported by a Juan de la Cierva fellowship. D.R. holds an FI Generalitat de Cataluña fellowship. We thank the Advanced Light Microscopy Unit and A. Mallabiabarrena for helping with the laser ablation experiments; K. Poss and H. Roehl for providing the tg(hsp70:zdnRAR) and tg(hsp70:fgf3) transgenic lines, respectively; C. Cañestro for sharing unpublished data; and members of the laboratory for helpful discussions and suggestions.

The authors declare no competing financial interests.

*D.R. and A.R.-M. contributed equally to this work.

Correspondence should be addressed to Dr. Berta Alsina, Laboratory of Developmental Biology, Department Experimental and Health Sciences, Universitat Pompeu Fabra-Parc de Recerca Biomèdica de Barcelona, Dr. Aiguader 88,08003 Barcelona, Spain. E-mail: Berta.alsina@upf.edu.

A. Robert-Moreno's present address: Centre de Regulació Genòmica, Parc de Recerca Biomèdica de Barcelona, 08003 Barcelona, Spain. this loss is unfortunately translated into deafness and balance deficits, two major medical problems in today's society. Differently from their mammalian counterparts, nonmammalian vertebrates can generate new hair cells after damage. In chick and amphibians, hair cells are produced de novo by direct transdifferentiation of supporting cells to hair cells and/or by reentry of supporting cells into cell division, giving rise to new hair cells and supporting cells (Corwin and Cotanche, 1988; Ryals and Rubel, 1988; Ma et al., 2008). Although regeneration-specific pathways have been uncovered recently (Hawkins et al., 2007; Liang et al., 2012), many pathways involved in the development of hair cells have also been implicated in their regeneration. For this reason, the most widely used strategies for generating new hair cells are blockade of the Notch pathway and overexpression of Atoh1 (Lindsell et al., 1996; Lanford et al., 1999; Stone and Rubel, 1999; 
Kawamoto et al., 2003; Izumikawa et al., 2005; Ma et al., 2008; Daudet et al., 2009; Millimaki et al., 2010; Wibowo et al., 2011; Mizutari et al., 2013). Transfection of Atoh1 leads to production of new hair cells in newborn mice, although these cells do not mature properly and complete hair cell regeneration is not achieved (White et al., 2006; Gubbels et al., 2008; Doetzlhofer et al., 2009). In parallel, Notch inhibition, which induces transdifferentiation of supporting cells to hair cells, leads to depletion of the supporting cell population, with consequences for long-term hearing recovery (López-Schier and Hudspeth, 2006; Lin et al., 2011; Mizutari et al., 2013; Slowik and Bermingham-McDonogh, 2013; Li et al., 2015). Therefore, discovering other mediators of hair cell regeneration that are capable of preserving the population of supporting cells would pave the way to new therapies for hearing restoration.

The retinoic acid (RA) pathway was found to have dramatic regenerative potential in amputated amphibian limbs (Niazi and Saxena, 1978; Maden, 1982; Gudas, 2012) and other organs, such as the heart, spinal cord sensory neurons, lung, and lens (Tsonis et al., 2000; Wong et al., 2006; Stinchcombe and Maden, 2008; Kikuchi et al., 2011). During adult zebrafish heart and fin regeneration, aldh1a2 expression is induced to mediate progenitor proliferation and survival (Kikuchi et al., 2011; Blum and Begemann, 2012). Recently, supporting cells of the zebrafish and axolotls lateral line have been shown to have RA pathway activity or express aldh1a2, suggesting that RA pathway could participate in hair cell regeneration (Monaghan and Maden, 2012; Pittlik and Begemann, 2012). In vitro studies indicated a role of exogenous RA in mouse and chick hair cell differentiation during embryonic development (Represa et al., 1990; Kelley et al., 1993), as well as in promoting hair cell regeneration in damaged organ of Corti of newborn mice (Lefebvre et al., 1993). To date, the cellular and molecular mechanisms of action of RA in hair cell regeneration need yet to be explored.

Here, we use genetic and pharmacological inhibition of RA signaling in zebrafish to uncover that the RA pathway is required for hair cell regeneration in the inner ear and also in the lateral line by promoting cell proliferation of supporting cells. Components of the RA pathway are activated before other well-known pathways, suggesting that it might be one of the earliest signals to induce hair cell regeneration. Specifically, we show that the RA pathway is required to repress $p 27^{k i p}$ and sox 2 transcription in neuromast supporting cells, two essential genes for sensory development, but does not interact with the Fgf pathway. The regulation of the cell cycle through $p 27^{k i p}$ would allow supporting cells to reenter the cell cycle. Finally, we use genetic cell-lineage tracing to show that new hair cells derive from FGF-active supporting cells. Together, our results demonstrate that RA signaling is a critical trigger of the molecular cascade necessary for hair cell regeneration.

\section{Materials and Methods}

Fish maintenance and zebrafish transgenic lines. Zebrafish were maintained at the Parc de Recerca Biomèdica de Barcelona Animal Facility under standard conditions. Zebrafish experimentation followed the European regulations and were approved by the Institutional Animal Care and Use Committee, Comité Ético de Experimentación Animal-Parc de Recerca Biomèdica de Barcelona (approved number JIB-08-1098P2). The following zebrafish transgenic lines of either sex were used: $\operatorname{tg}$ (brn3c:mGFP) (Xiao et al., 2005), $\operatorname{tg}$ (hsp70:dnraraa-GFP) (Kikuchi et al., 2011), $\operatorname{tg}($ erm:gal4;UAS:kaede) (Esain et al., 2010), $\operatorname{tg}($ hsp70: fgf3) (Lecaudey et al., 2008), tg(claudinb:GFP) (Haas and Gilmour, 2006), and $\operatorname{tg}$ (Xla.Eef1a1:H2B-Venus) (Recher et al., 2013). We chose the dominant negative form of the retinoic acid receptor (RAR) $\alpha$ a to block RA pathway because this mutant is the most potent of these inhibitory receptor mutants (Damm et al., 1993). Embryos were developed in an incubator at $28.5^{\circ} \mathrm{C}$ in system water containing methylene blue and staged according to standard protocols (Kimmel et al., 1995).

Laser ablation of lateral crista hair cells and blockade of the RA pathway. Double transgenic $\operatorname{tg}$ (brn3c:mGFP;hsp70:dnraraa-GFP) embryos were obtained by pairwise mating of adult carriers; 4.5 -d-old larvae were anesthetized using Tricaine $20 \mu \mathrm{M}$ (Sigma-Aldrich) and embedded on their sides in $1 \%$ low melting point agarose (Ecogen). Lateral crista hair cells were photoablated on SP5 upright Leica confocal microscope using a $25 \times$ water dipping objective and a two-photon laser beam (65-90\% intensity for 3-6 s, depending on the experiment). To avoid damaging the entire sensory patch, only the upper row of hair cells were targeted, with $70 \%-80 \%$ of hair cells ablated.

After laser ablation of the lateral crista, transgenic larvae were heatshocked at $39^{\circ} \mathrm{C}$ in prewarmed fish water for $45 \mathrm{~min}$ to $1 \mathrm{~h}$. The hair cells expressing membrane GFP (mGFP) were imaged using an SP2 Leica confocal microscope at different time points: $2,48 \mathrm{~h}$ postablation (hpa) and $6 \mathrm{~d}$ postablation (dpa). A second short 20 min heat-shock was performed at $20 \mathrm{hpa} . \mathrm{z}$-stacks spanning the entire crista (ablated lateral crista and posterior nonablated crista as an internal control) were taken at each time point (one $z$-plane imaged every $2-4 \mu \mathrm{m}$ ) using a SP2 Leica microscope. Raw data were analyzed, and hair cells were counted with FIJI software (Schindelin et al., 2012).

DiAsp staining of mature hair cells. In another set of experiments, hair cell regeneration was analyzed by counting the generation of matured hair cells in the inner ear. Before laser ablation, mature hair cells were labeled with $5 \mathrm{mg} / \mathrm{ml}$ of the fluorescent vital dye DiAsp that exclusively labels cells with active mechanotransducing channels. Briefly, DiAsp solution was injected into the inner ear of 4.5-d-old wild-type or $\operatorname{tg}($ hsp70:dnraraa-GFP) larvae. One hour later, DiAsp-stained lateral crista was laser-ablated and heat-shocked only once to block the RA pathway (see above). Regeneration in ablated lateral crista was assessed at $48 \mathrm{~h}$ and $6 \mathrm{dpa}$ by injecting DiAsp into the inner ear before confocal imaging.

Pharmacological loss-of-function studies. Pharmacological blockade of RA activity was performed by incubating larvae with $100 \mathrm{~mm}$ of the RA synthesis inhibitor DEAB (Sigma-Aldrich) in system water or DMSO as a control just after laser ablation of hair cells. DEAB was changed every $12 \mathrm{~h}$ and maintained during the $6 \mathrm{~d}$ regeneration period. The hair cells of lateral crista of $\operatorname{tg}(\mathrm{brn} 3 \mathrm{c}: \mathrm{mGFP})$ larvae were imaged at $4,48 \mathrm{hpa}$, and 6 dpa.

Neomycin induced hair cell damage to assess hair cell regeneration in the lateral line. Hair cell damage in the lateral line was induced by treating 4.5-d-old $\operatorname{tg}$ (brn3c:mGFP) or $\operatorname{tg}$ (brn3c:mGFP;hsp70:dnraraa-GFP) zebrafish larvae with $250-500 \mu \mathrm{m}$ of neomycin trisulphate salt hydrate (Sigma-Aldrich) in system water for $1 \mathrm{~h}$ as reported previously (Harris et al., 2003). Following neomycin treatment, larvae were washed extensively and allowed to recover for $3 \mathrm{~h}$ before DiAsp staining and live imaging. Some young and not fully mature Brn3cpositive hair cells that survived to antibiotic administration could be imaged at $4 \mathrm{~h}$ post-treatment (hpt); therefore, neuromasts were easily detected (data not shown). Counting of brn3c-positive and DiAsp stained-cells was performed at 12,24, and $48 \mathrm{hpt}$ in every individual neuromast.

$B r d U$ incubation and immunohistochemistry. Lateral crista: lateral crista hair cells of 4.5-d-old $\operatorname{tg}$ (brn3c:mGFP;hsp70:dnraraa-GFP) and $\operatorname{tg}($ brn3c:mGFP) larvae were laser-ablated as previously described, and larvae were heat-shocked at $39^{\circ} \mathrm{C}$ for $1 \mathrm{~h} ; 24 \mathrm{hpa}$, larvae were treated with $10 \mathrm{~mm}$ BrdU (Sigma-Aldrich) for $24 \mathrm{~h}$, washed two times, and fixed in $4 \%$ PFA. After several washes with $0.1 \%$ PBT, larvae were embedded in $7.5 \%$ gelatin/15\% sucrose. Blocks were frozen in 2-methylbutane (SigmaAldrich) for tissue preservation and cryosectioned at $20 \mu \mathrm{m}$ on a Leica CM 1510-1 cryostat.

Neuromast. The 4.5-d-old tg(claudinb:GFP;hsp70:dnraraa-GFP) and $\operatorname{tg}$ (claudinb:GFP) larvae were treated with $250-500 \mu \mathrm{m}$ of neomycin trisulphate salt hydrate and heat-shocked at $39^{\circ} \mathrm{C}$ for $1 \mathrm{~h}$. After washing the larvae, they were allowed to recover and were treated with $10 \mathrm{~mm}$ 
BrdU (Sigma-Aldrich) for $6 \mathrm{~h}$ at $9 \mathrm{hpt}$ and $34 \mathrm{hpt}$. Larvae were fixed in $4 \%$ PFA and washed several times with $0.1 \%$ PBT.

Immunohistochemistry. After a DNA denaturation step in $2 \mathrm{~N} \mathrm{HCl}$ for $30 \mathrm{~min}$ at room temperature, larvae (sections to reveal BrdUpositive cells in the inner ear) were washed three times in $0.1 \mathrm{M}$ sodium borate for $15 \mathrm{~min}$, washed in $0.1 \%$ PBT, and blocked in $0.1 \%$ PBT, $3 \%$ BSA, and $10 \%$ normal goat serum for $1 \mathrm{~h}$ at room temperature. Mouse anti-BrdU (Sigma; 1:200) and rabbit anti-GFP (Torrey Pinnes; $1: 400$ ) were incubated overnight at $4^{\circ} \mathrm{C}$ in blocking solution. After washing in $0.1 \%$ PBT for the whole day, anti-rabbit Alexa-488 and anti-mouse Alexa-648 (Invitrogen; 1:400) were incubated overnight at $4^{\circ} \mathrm{C}$ in blocking solution.

Neuromast hair cell regeneration time-lapse. The 4.5-d-old $\operatorname{tg}(\mathrm{Xla}$. Eef1a1:H2B-Venus;brn3c:mGFP;hsp70:dnraraa-GFP) triple transgenic larvae were treated with $250-500 \mu \mathrm{m}$ of neomycin trisulphate salt hydrate and heat-shocked at $39^{\circ} \mathrm{C}$ for $1 \mathrm{~h}$. To perform the imaging, we used a confocal sequential acquisition mode of two channels: (1) excitation at $488 \mathrm{~nm}$ (good excitation wavelength for GFP and poor one for venusFP) and detection window was optimized to detect GFP emmision and minimize venusFP emission (green color was assigned to this channel for presentation purposes); and (2) excitation at $515 \mathrm{~nm}$ (good excitation wavelength for venusFP and also excites GFP) and detection window was optimized to maximize venusFP emission detection (red color was assigned to this channel for presentation purposes). With these settings, in channel 1 we only detect the signal from the dnRAR-GFP fusion, whereas in channel 2 signals both nuclear FP were detected (the membrane of hair cells coming from brn3c-mGFP signal is observed in red in the video because the increased sensitivity settings for channel 2). The video displays an overlay of the two channels showing $\mathrm{GFP}^{-}$nuclei in red and $\mathrm{GFP}^{+}$nuclei in yellow (expressing both FPs). $z$-stacks of $50 \mu \mathrm{m}$ were collected for every time point, and a $z$-projection of maximal intensity comprising $\sim 10 \mu \mathrm{m}$ depth (10 slices including all nuclei from the neuromast) was obtained to generate the video for presentation. The time lapse was performed during $9 \mathrm{~h}$. Divisions were identified by a detailed $4 \mathrm{D}$ analysis of every plane.

Cell lineage. $\operatorname{Tg}($ brn3c:mGFP;erm:Gal4;UAS:Kaede) embryos were obtained by pairwise mating of adult carriers. Hair cells from lateral crista of 4.5-d-old larvae were ablated as described above and immediately afterwards the Kaede protein of that crista was photoconverted from green to red by exposure to UV light ( $12.5 \times$ intensity for $10 \mathrm{~s})$. Larvae were imaged at $48 \mathrm{hpa}$ using a Leica SP5 confocal microscope.

In the case of the neuromast, Kaede photoconversion was performed $3 \mathrm{~h}$ after neomycin treatment. Immediately after photoconversion, $z$-stacks spanning the entire neuromast were taken every $10 \mathrm{~min}$ (one $z$-plane imaged every $1 \mu \mathrm{m}$ ) using a Leica SP5 confocal microscope for $3 \mathrm{~h}$ (from 3 to $6 \mathrm{hpt}$ ). The larvae were again imaged every $10 \mathrm{~min}$ between 12 and $21 \mathrm{hpt}$ and at 30 and $50 \mathrm{hpt}$ using a Leica STED confocal microscope. Raw data were analyzed, and hair cells were counted with Fiji software (Schindelin et al., 2012).

Whole-mount in situ hybridization. Synthesis of antisense RNA and whole-mount in situ hybridization were performed as previously described (Thisse et al., 2004). The following probes were used: atoh1a (Millimaki et al., 2007), aldh1a3 (Cañestro et al., 2009), cyp26a1, cyp26b1, and cyp26c1 (White et al., 2007), sox2 (März et al., 2010), cdkn1b (Geling et al., 2003), and $f_{g} f 3$ (Maves et al., 2002). rarab and rarga probes were generated by PCR amplification from $72 \mathrm{hpf}$ embryos cDNA, adding $\mathrm{T} 7$ polymerase binding side at $5^{\prime}$ of the reverse primers and following RNA transcription. rarab primers: forward, 5'-GATGTGTGGTTTGTGTGG CCTTC-3' ${ }^{\prime}$, and reverse, $5^{\prime}$-TAATACGACTCACTATAGGGATGCCTT CCCCTCGCTCTGTCAG-3'; rarga primers: forward, 5' -CGAGGCTA GGAACAGCTCAC-3', and reverse, 5'-TAATACGACTCACTATA GGGATGCAAGCAGGCAGATTTGAGAAGG-3'.

After in situ hybridization, embryos were postfixed overnight in $4 \%$ PFA and analyzed in whole mount for neuromast imaging (larvae mounted in $100 \%$ glycerol) or in sections for inner ear expression analysis (larvae embedded in $7.5 \%$ gelatin/15\% sucrose). Blocks were frozen in 2-methylbutane (Sigma-Aldrich) for tissue preservation and cryosectioned at $20 \mu \mathrm{m}$ on a Leica CM 1510-1 cryostat.
Immunostaining with rabbit anti-GFP (Torrey Pines, 1:400) and donkey anti-rabbit AlexaFluor-488 (Invitrogen, 1:400) was performed to detect cells expressing brn3c:mGFP and/or the fusion protein dnRAR-GFP.

Statistics. All statistical comparisons were performed by unpaired Student's $t$ test. In figures mean and SD values are shown.

\section{Results}

\section{Blockade of RA signaling impairs hair cell regeneration in the lateral crista}

To assess the role of RA signaling in hair cell regeneration in the inner ear in vivo, we ablated hair cells using 2-photon microscopy and quantitatively analyzed the dynamics of new hair cell generation with and without RA signaling. We took advantage of the $\operatorname{tg}$ (brn3c:mGFP) transgenic line, which specifically labels the body membranes and kinocilia of hair cells present in the various sensory patches of the inner ear (three cristae and two maculae) (Xiao et al., 2005). In vivo GFP labeling of hair cell membranes was detected in the three sensory cristae of the inner ear (Fig. 1A): lateral crista (lc), posterior crista (pc), and anterior crista (ac) in confocal microscopy reconstructed stacks. The number of hair cells in each crista can be quantified in individual $z$-stacks (Fig. $1 C^{\prime}$ ). Hair cells of the lc (the most superficial and accessible crista) were damaged using 2-photon microscopy laser ablation in $4.5 \mathrm{~d}$ postfertilization (dpf) larvae to induce hair cell regeneration (Fig. $1 A, B, D$ ). The conditions of laser ablation were set to ensure that the supporting cell layer was not damaged. Immediately following laser ablation, RA signaling was blocked by overexpressing a dominant negative form of the RA receptor fused to GFP (dnRARaa-GFP), a strategy previously reported to efficiently block RA signaling (Kikuchi et al., 2011; Blum and Begemann, 2012). The dnRAR-GFP protein (referred here as dnRAR) was induced by heat-shock immediately after laser ablation and again at 20 hpa (Fig. 1E). The number of hair cell kinocilia and cell bodies was reduced by $72 \%$ in the lc of 2 hpa larvae with intact and inhibited RA pathway (Fig. $1 F, I$ ). We then counted the number of hair cells at $48 \mathrm{hpa}$ and found that it was significantly reduced in RA-depleted larvae compared with non-RA-depleted larvae (the control larvae dnRAR-negative were also heatshocked for proper comparison) $\left(\right.$ dnRAR $^{-}: 9.25 \pm 3.2$; dn$\operatorname{RAR}^{+}: 3.2 \pm 2.3$; Fig. $\left.1 F, G, I, J, M\right)$. A reduction in the total number of hair cells in RA-depleted larvae was still evident $6 \mathrm{~d}$ after laser ablation but was not significant due to the progressive dilution of the dnRAR protein (Fig. $1 H, K, M$ ). In the posterior crista (pc), in which hair cells were not laser-ablated, the blockade of RA signaling had no effect on hair cell number, showing a specific requirement of RA activity during hair cell regeneration (Fig. $1 L$ ).

To further confirm the role of RA, we again overexpressed the dnRAR, but this time hair cells were labeled with DiAsp, a vital dye that enters mechano-active hair cells and stains their cytoplasm red (Hernandez et al., 2006) (Fig. 2A,B). As in the previous experiment, after counting labeled hair cells of the ablated lc and nonablated pc, we found that RA blockade significantly impaired the production of new hair cells at $48 \mathrm{hpa}\left(\mathrm{dnRAR}^{-}: 7.66 \pm 1.5\right.$; dnRAR ${ }^{+}: 4.5 \pm 0.6$; Fig. $2 D$ ). Again, dnRAR did not have any effect on the number of hair cells in nonablated crista (Fig. 2C). Finally, using another approach to inhibit RA signaling, we pharmacologically treated the laser-ablated larvae with the DEAB inhibitor that impairs the enzymatic activity of Aldh1 enzymes. In consequence, DEAB-treated larvae have reduced RA levels in tissues. In these experiments, hair cell regeneration was again impaired in RA-depleted but not in non-RA-depleted larvae (Fig. $2 F)$. RA inhibition did not have any effect on nonablated hair 

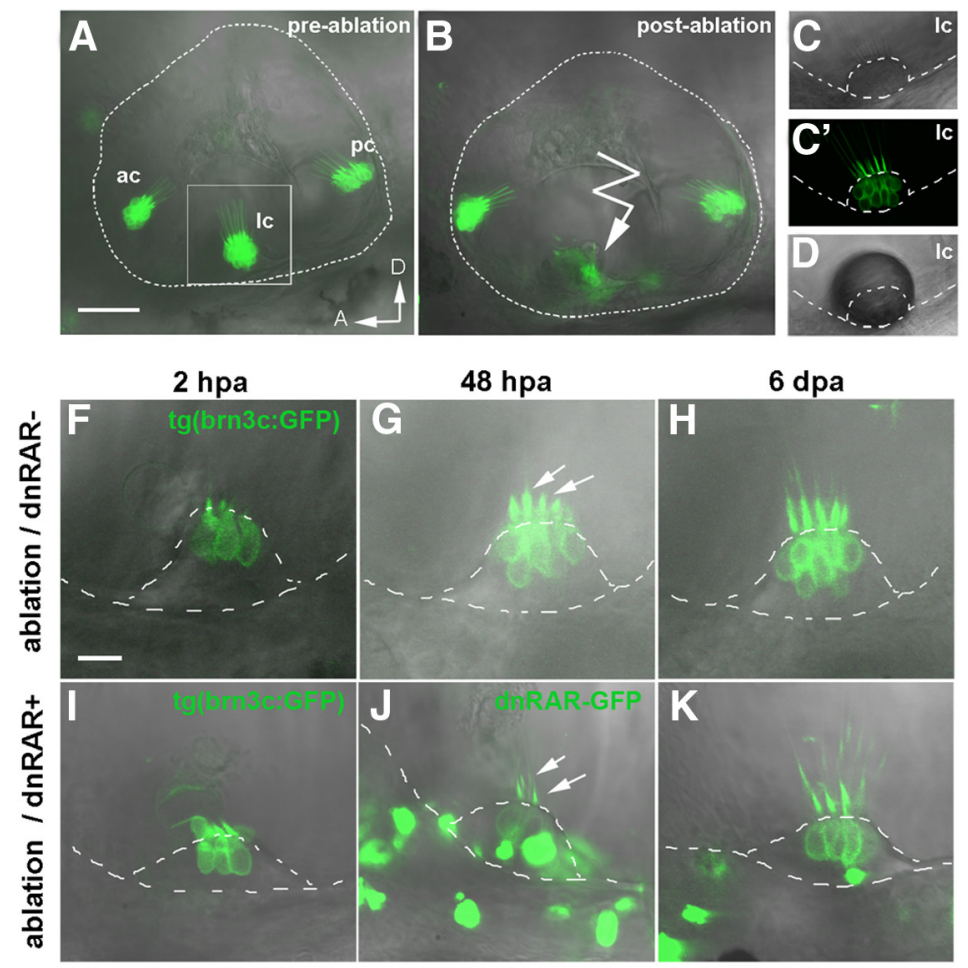
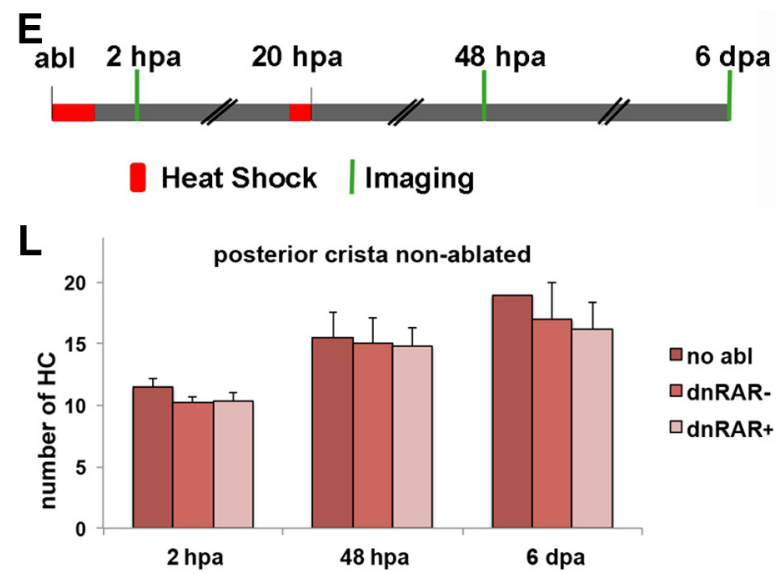

M

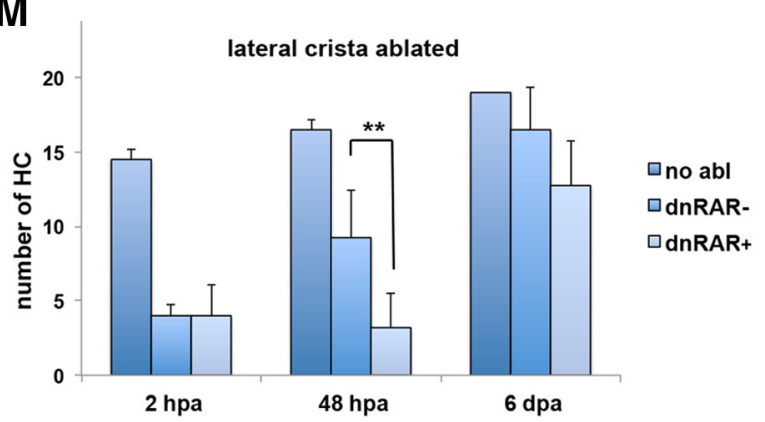

Figure 1. RAR activity is required for hair cell regeneration in the inner ear. $\boldsymbol{A}-\boldsymbol{D}$, Inner ear of 4.5-d-old tg(brn3c:mGFP) larvae with GFP labeling of hair cells in the three sensory cristae before ( $\boldsymbol{A}$ ) and after ( $\boldsymbol{B}$ ) lateral crista hair cell 2-photon laser ablation (detail, right). $\boldsymbol{C}, \boldsymbol{C}^{\prime}$, High magnification view of the lateral crista showing hair cell bodies and kinocilia labeled with membrane-GFP. $\boldsymbol{D}$, A transient air bubble over the crista is generated after laser ablation. $\boldsymbol{E}$, Schematic representation of experimental procedure to assess the role of RA in hair cell regeneration in the inner ear. Briefly, after laser ablation of the lateral crista, two heat-shocks were performed to induce dnRAR expression, and hair cell number was quantified at $2 \mathrm{hpa}, 48 \mathrm{hpa}$, and $6 \mathrm{dpa}$. $\boldsymbol{F}-\boldsymbol{K}$, Representative examples of hair cell regeneration in the Ic after laser ablation in non-dnRAR $(\boldsymbol{F}-\boldsymbol{H})$ and dnRAR-expressing larvae $(\boldsymbol{I}-\boldsymbol{K}) . \boldsymbol{G}, \boldsymbol{J}$, Arrows indicate kinocilia of the ablated crista at $48 \mathrm{hpa}$. $\boldsymbol{J}, \boldsymbol{K}, \mathrm{dnRAR}$-GFP is visible in the inner ear. $\boldsymbol{L}, \boldsymbol{M}$, Quantitative analysis of the number of hair cells at different time points in nonablated posterior crista $(\boldsymbol{L})$ and ablated lateral crista $(\boldsymbol{M})$. $A$, Anterior; $D$, dorsal; ac, anterior crista; Ic, lateral crista; $p c$, posterior crista. ${ }^{* *} p<0.01$. Scale bars: $A, 50 \mu \mathrm{m} ; \boldsymbol{F}, 10 \mu \mathrm{m}$.

cells (Fig. 2E). Because the Aldh1 inhibitor was present throughout the regeneration period, in comparison with the dnRAR overexpression experiment, regeneration was significantly impaired at both $48 \mathrm{hpa}$ and $6 \mathrm{dpa}$ (48 hpa DMSO: $19.2 \pm 1.3$; DEAB: $18.25 \pm 1.3$ and 6 dpa DMSO: $20.2 \pm 0.84$; DEAB: $17.6 \pm$ 1.4). Together, these three different experimental approaches provide new evidence that the RA pathway is required for hair cell regeneration in the zebrafish inner ear.

$\mathrm{RA}$ is also required for hair cell regeneration in the lateral line The zebrafish has a second mechanosensory organ, the lateral line, distributed along the body that detects local disturbances of water flow. The lateral line is composed of neuromasts with rosettes of hair cells on top of supporting cells and covered by a single sheet of mantle cells (Williams and Holder, 2000). This superficial sensory organ has been widely used in hair cell regeneration studies because of its ease of imaging and damaging hair cells by aminoglycoside treatment. Thus, we also decided to evaluate the effects of the RA pathway in lateral line hair cell regeneration and compare these results with those found in the inner ear. It has been shown that 4.5-d-old larvae exposed to 250-500 $\mu \mathrm{M}$ neomycin for a period of $1 \mathrm{~h}$ become devoid of all hair cells at $4 \mathrm{hpt}$ and that a peak of supporting cell proliferation takes place by $12 \mathrm{hpt}$ (Harris et al., 2003). We followed the same strategy to induce hair cell regeneration and, in parallel, inhibited the RA pathway by overexpressing the dnRAR protein with two heatshocks: one just after neomycin exposure and a second one at 20 hpt. The DiAsp-labeled hair cells of several neuromasts were time-lapse imaged and quantified (Fig. 3A). As expected, at $4 \mathrm{hpt}$ almost no mature hair cells were present in neuromasts treated with neomycin in non-dnRAR and dnRAR-overexpressing larvae (Fig. 3 E, H; compared with Fig. 3B). Interestingly, at $24 \mathrm{hpt}$, hair cell generation was significantly impaired after RA blockade compared with control sibling larvae $\left(24 \mathrm{hpt} \mathrm{dnRAR}^{-}: 5.5 \pm\right.$ 1.29; dnRAR ${ }^{+}: 1.45 \pm 1.36$; Fig. $\left.3 F, I, K\right)$. The effect on new hair cell production was also observed at $48 \mathrm{hpt}$, albeit at a lesser extent ( 48 hpt dnRAR ${ }^{-}: 8.25 \pm 2.2$ dnRAR $^{+}: 4.75 \pm 1.83$; Fig. $3 G, J, K)$. Because the total number of hair cells in each neuromast can vary slightly along the posterior line, the same neuromasts were used in each larva to count hair cell numbers (positions p1-p2-p3 from Harris et al., 2003). New generated hair cells, labeled with DiAsp, did not present GFP staining, suggesting that supporting cells expressing high dnRAR cannot proceed to become hair cells (Fig. $3 I, J$ ).

\section{Regulation of supporting cell proliferation by RA pathway}

To explore whether RA signaling impairs regeneration through the control of cell proliferation, we labeled S-phase cells in the inner ear and lateral line in homeostasis and upon regeneration induction.

Ablated and nonablated lateral crista of $\operatorname{tg}($ brn3c:mGFP $) 4.5$ $\mathrm{dpf}$ larvae were left to incorporate BrdU for a period of $24 \mathrm{~h}$ (from $24 \mathrm{hpa}$ until $48 \mathrm{hpa}$ ). We could detect a high number of BrdUpositive supporting cells adjacent to the central patch of differentiated hair cells in the ablated crista (Fig. $4 B$ ) but not in the nonablated crista (Fig. 4A), indicating that cell proliferation is 
A

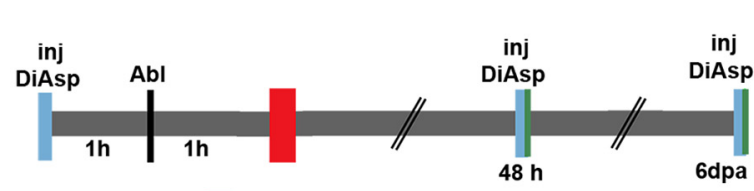

Heat Shock | imaging

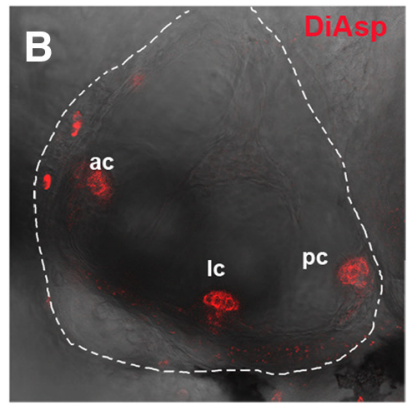

\section{DiAsp staining}

C

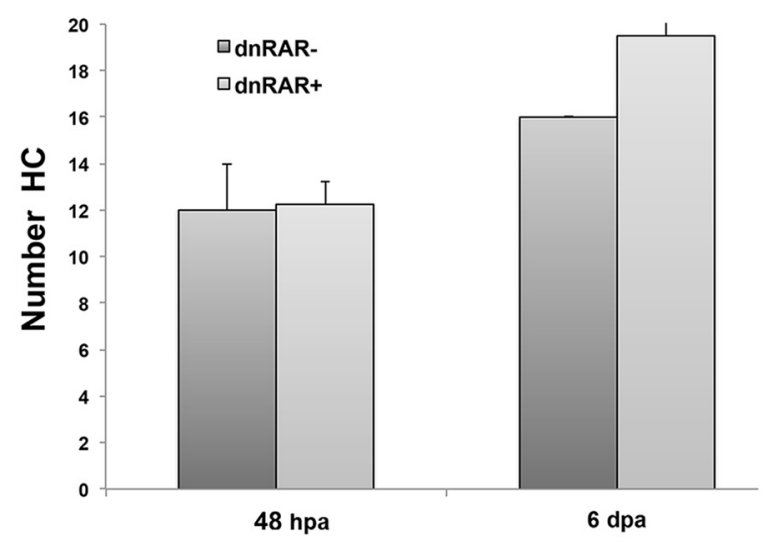

Pharmacological RA inhibition

E

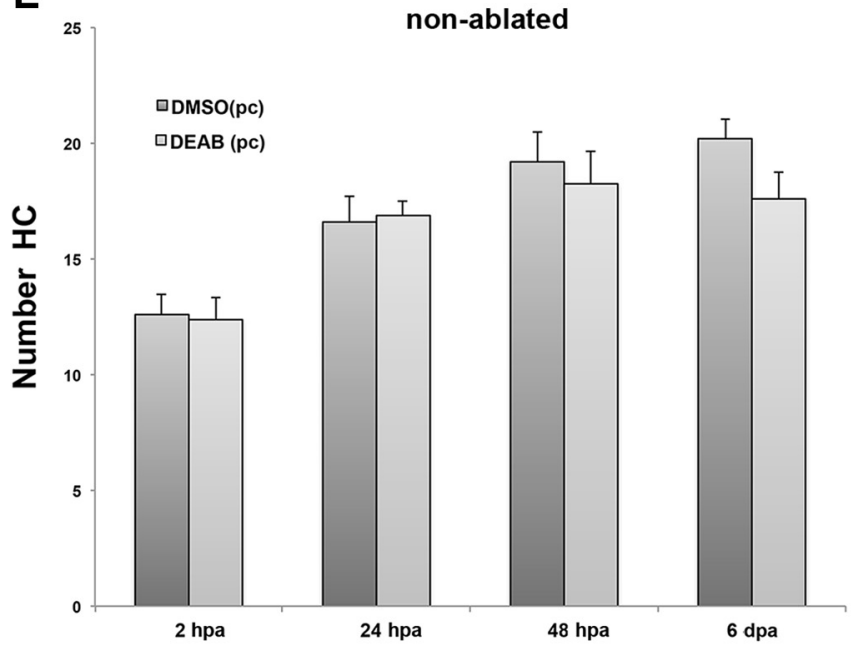

D

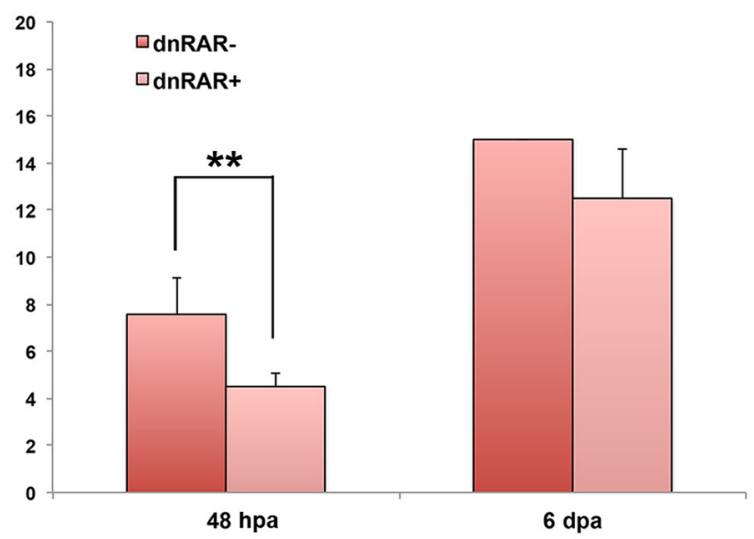

$\mathbf{F}$

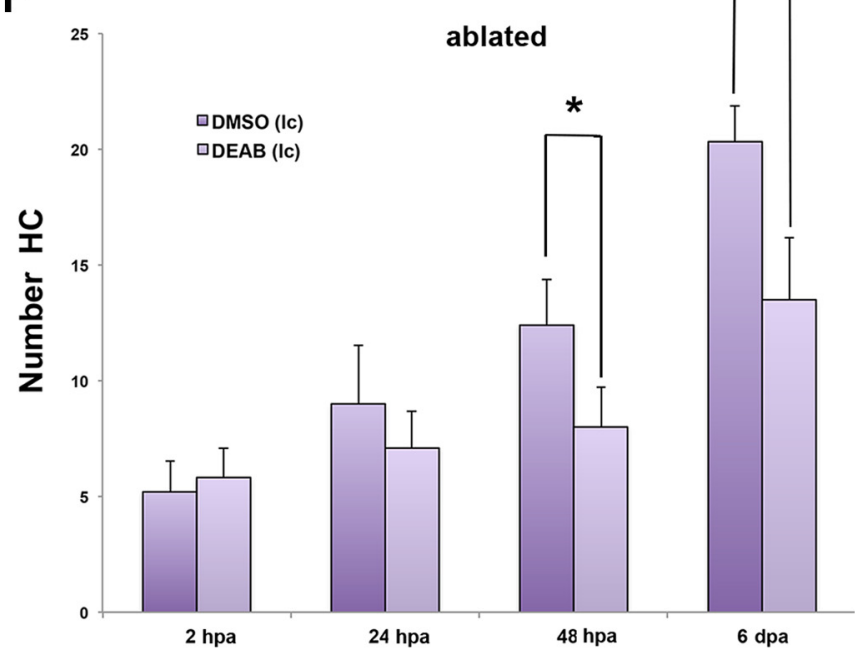

Figure 2. DiAsp staining and blockade of RA activity with DEAB confirm that RAR activity is required for hair cell regeneration. $\boldsymbol{A}$, Hair cell regeneration was evaluated by labeling hair cells with DiAsp, which labels mature hair cells. Schematic representation of experimental procedure: a $45 \mathrm{~min} 1 \mathrm{~h}$ heat-shock was performed $1 \mathrm{~h}$ after lateral crista laser ablation. Before laser ablation and imaging (48 hpa and $6 \mathrm{dpa}$ ), a DiAsp solution was injected into the inner ear lumen. $\boldsymbol{B}$, Inner ear reconstructed view of the three cristae labeled with DiAsp. $\boldsymbol{C}, \boldsymbol{D}$, Hair cell regeneration in ablated crista is significantly impaired at $48 \mathrm{hpa}$ in dnRAR-expressing larvae (D). In nonablated crista, overexpression of dnRAR does not affect the number of hair cells (C). $\boldsymbol{E}$, $\boldsymbol{F}$, RA synthesis was pharmacologically inhibited in 4.5-d-old tg(brn3c-mGFP) larvae using DEAB, an inhibitor of aldh1 activity. Brn3c GFP-positive hair cells were imaged and quantified at 2, 24, and 48 hpa and 6 dpa in DMSO- and DEAB-treated larvae. $\boldsymbol{F}$, Blockade of RA synthesis significantly impairs $\mathrm{HC}$ regeneration at $48 \mathrm{hpa}$ and $6 \mathrm{dpa}$. In nonablated crista, DEAB treatment does not affect the number of hair cells $(\boldsymbol{E})$. ${ }^{*} p<$ 0.05. ${ }^{* *} p<0.01$. ac, anterior crista; Ic, lateral crista; $p c$, posterior crista. Scale bars: $\boldsymbol{A}, 50 \mu \mathrm{m} ; \boldsymbol{F}, 10 \mu \mathrm{m}$.

induced upon hair cell damage in the lateral crista. We also checked whether dnRAR-expressing cells could incorporate BrdU by repeating the same experiment but inducing the expression of dnRAR after laser ablation. In this experiment, we again found increased numbers of BrdU-positive cells in ablated lateral crista (Fig. $4 D$, arrowheads), compared with nonablated crista (Fig. 4C). In both cases, dnRAR cells did not present BrdU staining, suggesting that dnRAR cells could not enter S-phase.

We next went to assess whether a similar blockade on cell proliferation by RA inhibition could be taking place in the lateral 
A

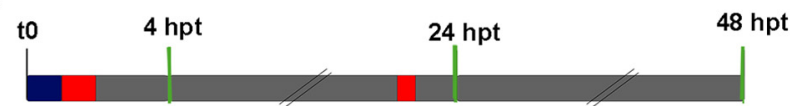

Neomycin treatment Heat-shock Imaging
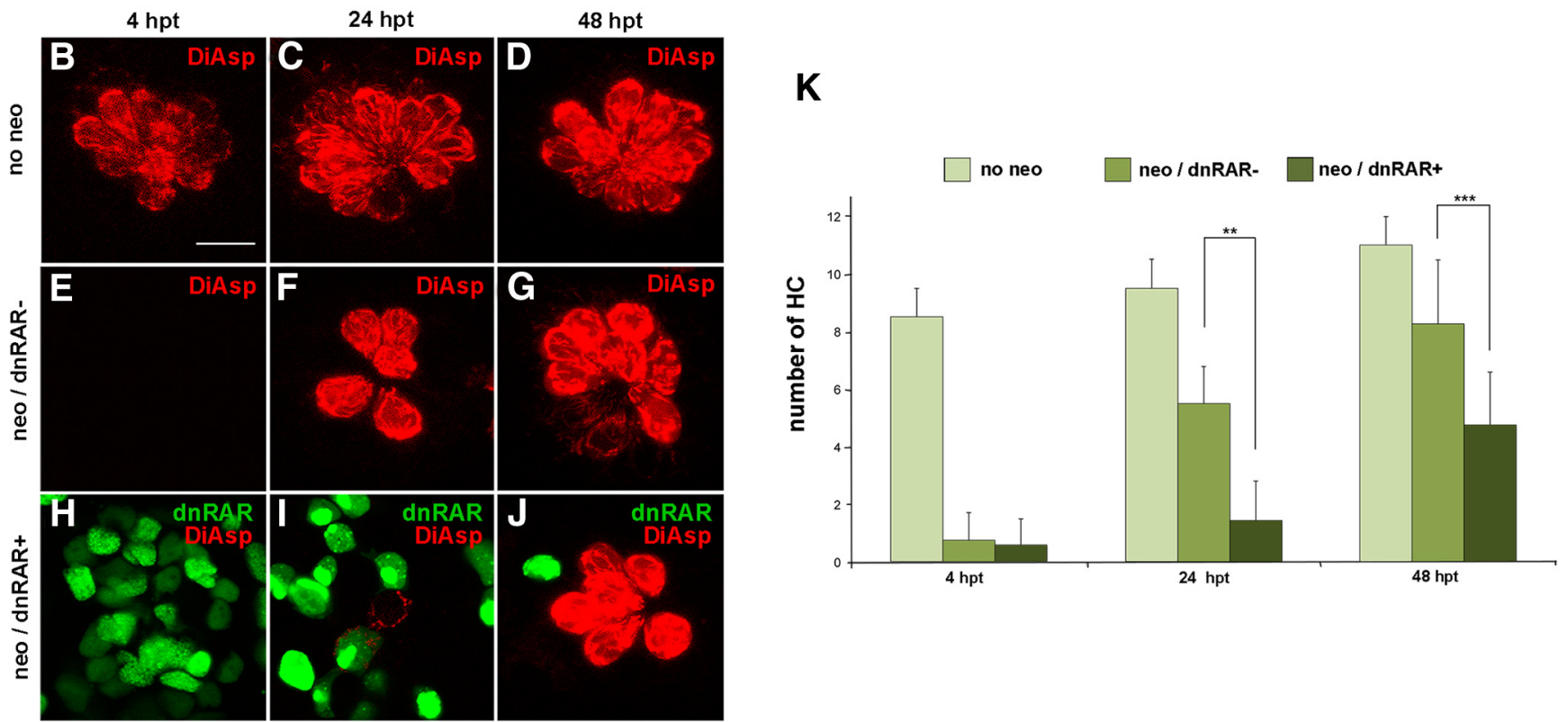

Figure 3. The RA pathway is required for neuromast regeneration. $\boldsymbol{A}$, Schematic representation of the experiment. Briefly, neuromast hair cell loss was induced by neomycin in 4.5-d-old non-dnRAR and dnRAR-expressing larvae, and heat-shocked to induce dnRAR-GFP expression. Hair cells were stained with DiAsp (red) at 4, 24, and 48 hpt to evaluate the regeneration progress. $\boldsymbol{B}-\boldsymbol{D}, \boldsymbol{z}$-stack projection of neuromast stained with DiAsp in nonregenerating conditions. $\boldsymbol{E}-\boldsymbol{G}$, Neuromast with no DiAsp-labeled hair cells $4 \mathrm{~h}$ after neomycin treatment (E) and with newborn hair cells at $24 \mathrm{hpt}$ and $48 \mathrm{hpt}(\boldsymbol{F}, \boldsymbol{G})$. $\boldsymbol{H}-\boldsymbol{J}$, 0verexpression of dnRAR (shown in green) impairs hair cell regeneration at $24 \mathrm{hpt}$ and $48 \mathrm{hpt}$, the effect being lower at $48 \mathrm{hpt}$ when dnRAR is downregulated $(\boldsymbol{I}, \boldsymbol{J}) . \boldsymbol{K}$, Quantitative analysis of the number of hair cells at different time points in non-dnRAR and dnRAR-overexpressing larvae. ${ }^{* *} p<0.01,{ }^{* * *} p<0.001$. Scale bar: $\boldsymbol{B}, 10 \mu \mathrm{m}$.

line. BrdU incorporation was performed for $6 \mathrm{~h}$ at two time points, at 9 and $34 \mathrm{~h}$ after neomycin treatment in wild-type and RA blocking conditions. Few or no BrdU-positive cells were detected under resting conditions, either with an intact or inhibited RA pathway (Fig. 4E,H). However, following neomycin treatment, an induction of S-phase was detected at $15 \mathrm{hpt}$ only in larvae with an intact RA pathway. While in regenerating neuromasts with intact RA signaling, many cells inside the neuromast are positive for BrdU (Fig. $4 F$ ); in RA-depleted larvae, a very limited number of cells entered S-phase (neo/dnRAR ${ }^{-}: 8 \pm 2$; neo/dnRAR ${ }^{+}: 1.17 \pm 1.47$ ) (Fig. $4 I$ ). Again, none of the BrdUpositive cells were dnRAR-expressing cells, indicating that RA inhibition prevents supporting cells from entering S-phase, and therefore generating new hair cells. In control larvae, incorporation of BrdU at $15 \mathrm{hpt}$ was observed in supporting cells in the center of the neuromasts (Fig. $4 F$ ) as previously reported (Ma et al., 2008). In RA-depleted larvae at $40 \mathrm{hpt}$, the dnRAR protein was diluted in neuromasts and extensive induction of cell proliferation was then observed in peripheral cells surrounding the neuromasts (Fig. $4 J$ ).

To have a better assessment of cell proliferation dynamics on dnRAR-positive and dnRAR-negative supporting cells during regeneration, we generated a triple transgenic larvae by crossing $\operatorname{tg}$ (Xla.Eef1a1:H2B-Venus) to label cell nuclei, with $\operatorname{tg}$ (brn3c: mGFP) to label nascent hair cells and with $\operatorname{tg}$ (hsp70:dnraraaGFP) to inhibit RA pathway. By imaging of cell nuclei in neomycin-treated larvae for a period of $9 \mathrm{~h}$ (from 15 to $24 \mathrm{hpt}$ ), 6 divisions of supporting cells are observed (nuclei observed in red and dnRAR cells in yellow). We followed dnRAR cells, and none of them divided during this period (in Movie 1, 5 divisions are shown in a period of $3 \mathrm{~h}$ ). During the imaged period of regeneration, no new brn3c-positive cells are observed, probably because brn $3 \mathrm{c}$ is a late marker of hair cell differentiation.

\section{Regenerated hair cells of the crista derive from FGF-active supporting cells}

To trace the origin of newly generated hair cells in the zebrafish inner ear and neuromast, we performed a genetic cell-tracing experiment. Several FGFs are expressed in sensory patches in the zebrafish and mouse inner ear throughout development (Pirvola et al., 2000; Pickles, 2001; Chapman et al., 2006; Hayashi et al., 2008). In mouse, FGF signaling mediated by FGFR1 maintains Sox2 expression in sensory progenitors (Ono et al., 2014), whereas FGFR3 signaling is required to inhibit transdifferentiation of supporting cells (Hayashi et al., 2007; Jacques et al., 2012). We found that erm (also named etv5), a downstream effector of the FGF pathway, is expressed exclusively in the zebrafish supporting cell population. Thus, we crossed the transgenic line tg(erm:Gal4;UAS:Kaede), which expresses photoconvertible Kaede protein in cells expressing erm, with fish with membrane GFP staining in hair cells (Fig. $5 A, B$ ). The hair cells of the lateral crista (lc) were then ablated, and Kaede protein of supporting cells was then photoconverted from green to red using a $10 \mathrm{~s} \mathrm{UV}$ pulse (Fig. 5C,D). At $48 \mathrm{hpa}$, the ablated lc presented an overall 
yellow staining due to a mixture of red and newly synthetized green Kaede protein in supporting cells. We observed several cells with only red cytoplasmic Kaede that displayed a GFP-labeled kinocilium, indicative of hair cell differentiation (Fig. $5 E, F)$. Because erm is not activated in hair cells, the presence of photoconverted red Kaede protein in these cells indicates their supporting cell origin (Fig. 5 E, F, arrows). In the same regenerating crista, cells devoid of Kaede protein and with membrane GFP staining were also found; presumably, those cells are hair cells that remained intact after laser ablation (Fig. $5 E$, arrowhead). Our experiments demonstrate that regenerated hair cells of the zebrafish inner ear originate from supporting cells, and differentiate in a short period of time since by 48 hpa differentiated hair cells with a kinocilium are already detected.

A similar cell-tracing experiment was done in the regenerating neuromast. There, GFP expression directed by erm also labels supporting cells, albeit in a patchy manner (Fig. 5G). We induced hair cell loss by neomycin treatment, and at $3 \mathrm{hpt}$ we photoconverted Kaede in supporting cells. We generated two videos, one from 3 to $6 \mathrm{hpt}$ and a second one from 12 to $21 \mathrm{hpt}$. During the first video, we could observe the appearance of two new hair cells with cytoplasmatic red Kaede and low brn $3 \mathrm{c}$ membrane staining that at $6 \mathrm{hpt}$ begin to display a kinocilium. These two new hair cells most probably arise from a hair cell precursor expressing erm at the moment of neomycin treatment. During the second video, we observed two high expressing erm cells that differentiate to hair cells by $19 \mathrm{hpt}$. No new hair cells are produced until after $30 \mathrm{hpt}$. At $50 \mathrm{hpt}$, we observed eight new hair cells, with cytoplasmatic red kaede indicating that these come from the photoconverted kaede population of supporting cells (Fig. 5G).

\section{Components of the RA signaling} pathway are activated upon hair cell loss

We next assessed the dynamics of the RA pathway activation during hair cell regeneration in the inner ear. Under basal conditions, one of the RA-synthetizing enzymes, aldh1a3, but not aldh1a2, is expressed in the sensory patches of $4.5 \mathrm{dpf}$ larvae. At the posterior macula, aldh1a3 expression is detected at the anterior side of the sensory patch, encompassing supporting cells and hair cells (lower layer and upper layers, respectively) (Fig. 6A, merged panels with GFP in hair cells). Otherwise, the expression of RA-degrading enzyme, cyp26b1, is detected only at the posterior side of the sensory patch (Fig. 6B). It has been already shown in many
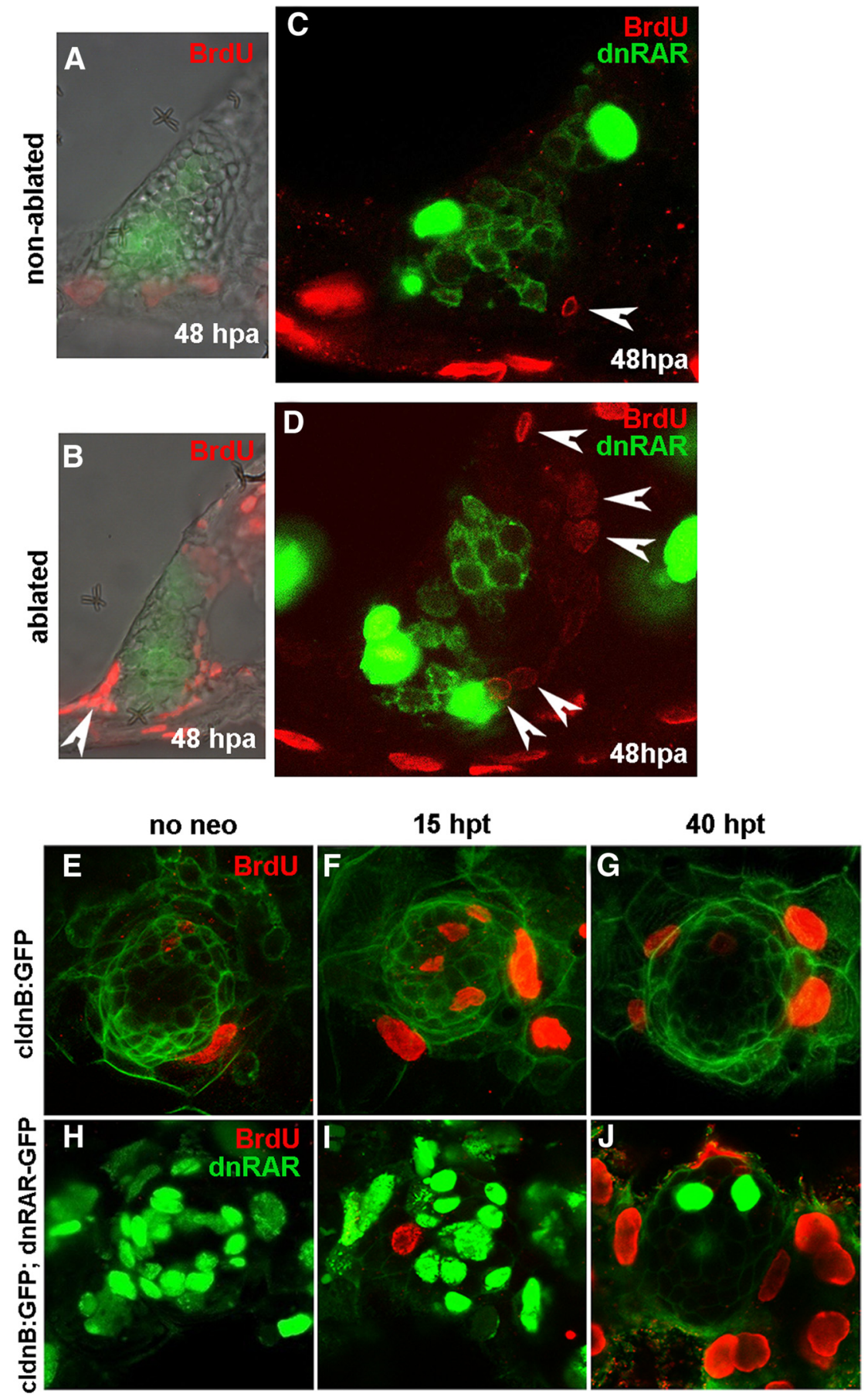

Figure 4. The RA pathway is required for supporting cell proliferation. $A-D$, To evaluate the role of RA in proliferation, lateral cristae of 4.5-d-old $\operatorname{tg}(\mathrm{brn} 3 \mathrm{c}: \mathrm{mGFP})$ and $\operatorname{tg}(\mathrm{brn3} 3 \mathrm{c}: \mathrm{mGFP}$;hsp70:dnRARaa-GFP) larvae were laser-ablated and heat-shocked to induce dnRAR-GFP expression after $1 \mathrm{~h}$. $\boldsymbol{A}, \boldsymbol{B}$, Increase of BrdU-positive cells was detected 48 hpa in treated larvae compared with the nonablated controls. $C, D$, Again, cell proliferation is induced in ablated lateral crista, and only non-dnRAR cells can enter the cell cycle (arrowheads). $\boldsymbol{E}-\boldsymbol{J}$, To confirm the results from the inner ear, 4.5-d-old tg(claudinb:GFP) and tg(claudinb:GFP;hsp70: dnRARaa-GFP) larvae were treated with neomycin and heat-shocked to induce dnRAR-GFP expression. $\boldsymbol{E}-\boldsymbol{G}$, The number of BrdU-positive cells (red) increased significantly $15 \mathrm{~h}$ after neomycin-induced hair cell damage in non-dnRAR larvae $(\boldsymbol{F})$. At $40 \mathrm{hpt}$, cell proliferation was mainly detected in mantle cells $(\mathbf{G}) . \mathbf{H}-\boldsymbol{J}$, Cell proliferation is very low at $15 \mathrm{hpt}$ in dnRAR-overexpressing larvae, and only non-dnRAR cells can enter the cell cycle (non-green cells) $(I)$. At $40 \mathrm{hpt}$, less dnRAR is present and extensive proliferation is found in external cells $(J)$.

tissues (e.g., hindbrain, limbs, and eye) that a gradient of RA activity is generated by the complementary expression of aldhs and Cyp26 enzymes, producing a graded response in gene expression throughout the tissue (Scadding and Maden, 1994; Dupé and Lumsden, 


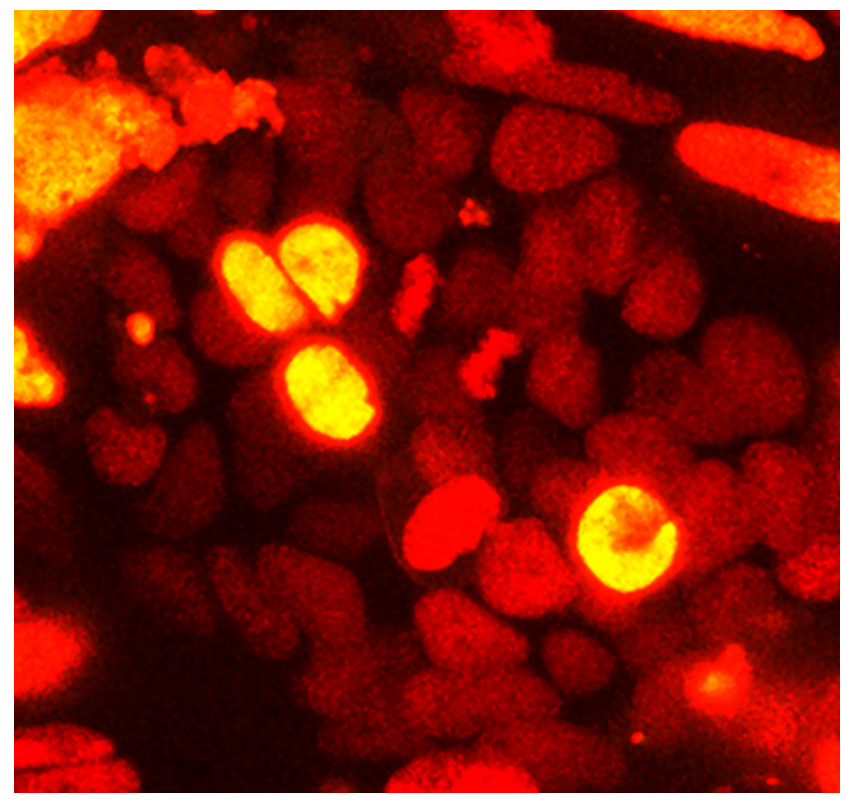

Movie 1. Imaging of supporting cell divisions in dnRAR larvae-regenerating neuromast. Cell division during regeneration only occurs in supporting cells not expressing dnRAR. Time-lapse of a neuromast during regeneration with nucleus of every cell shown in red ( $\mathrm{H} 2 \mathrm{~B}$-venus) and nucleus of dnRAR-expressing cells shown in yellow (H2B-venus and dnRAR-GFP). The membrane of a hair cell is also observed in red (mGFP). Arrowheads indicate the dividing nuclei, highlighting the nuclear condensation or chromosome segregation.

2001; Mey et al., 2001; White et al., 2007; Shimozono et al., 2013). In contrast, the RA receptor rarga is expressed throughout the sensory patch (Fig. 6C). In the lateral crista, aldh1a3 and cyp26b1 expression patterns are also complementary, displaying a mediolateral, instead of an anteroposterior, gradient axis (Fig. 6D,E). Again, rarga is expressed throughout the sensory patch (Fig. $6 F$ ).

Next, we sought to analyze whether any of the components of the RA pathway responds to the induction of hair cell regeneration upon laser ablation. When we analyzed the expression of the RA pathway genes $24 \mathrm{hpa}$ in the lateral crista, we observed that aldh1a3, cyp26b1, and rarga transcript levels were increased compared with nonablated crista (Fig. 6G-I). In particular, aldh1a3 expression seemed to extend to adjacent cells, whereas cyp26b1 and rarga transcript levels mainly increased in the cells already expressing them. These results indicate a general surge in the expression of the RA signaling pathway members during regeneration. In the regenerating neuromast, sox 2 is transiently downregulated just after hair cell loss (Jiang et al., 2014); thus, we checked the expression of sox 2 in the lateral crista after hair cell damage. After $4 \mathrm{hpa}$, we found that sox 2 expression was also reduced (Fig. $6 \mathrm{~J}, \mathrm{~K}$ ) and, as in the lateral line, the reduction seems to be transient because it could not be detected by 6 hpa (data not shown).

Next, we checked whether the RA pathway is also activated in the regenerating lateral line and assessed its temporal regulation. In nonregenerating conditions, aldh1a3 is not expressed in the neuromast, whereas rarga is expressed throughout the neuromast (Fig. 7). When regeneration was triggered by neomycin treatment, we find that expression of aldh1a3, rarab, and cyp26al is induced at $1.5 \mathrm{hpt}$ (Fig. 7). In particular, induced expression of cyp26a1 does not occur in all neuromasts; and when observed, it is restricted to two adjacent cells (Fig. 7). Expression of cyp26c1 increased at $3 \mathrm{hpt}$; and interestingly, its expression was mainly restricted to the dorsoventral poles of the neuromast. Together, the activation of the RA pathway components was very rapid and transient because aldh1a3 and cyp26c1 expressions were already downregulated at $12 \mathrm{hpt}$ (Fig. 7). In concert with the activation of the RA pathway, as already shown, other essential genes for hair cell development also changed their transcript levels: sox 2 and atohla (found in supporting cells and hair cells, respectively) were downregulated and upregulated at $1.5 \mathrm{hpt}$, respectively (Fig. 7) (Hernandez et al., 2006; Jiang et al., 2014). These data indicate that RA might be one of the earliest signaling pathways activated in hair cell regeneration.

\section{The RA pathway blockade impairs the downregulation of sox 2 and $\mathrm{p} 27^{\mathrm{kip}}$ expression in supporting cells}

During development of the murine organ of Corti, the cyclindependent kinase inhibitor $p 27^{k i p}$ is essential for the cessation of progenitor cell division and the subsequent differentiation of supporting cells and hair cells (Chen and Segil, 1999). Moreover, previous studies demonstrate that the proliferative capacity of supporting cell is directly linked to their ability to downregulate $p 27^{k i p}$ in mouse (White et al., 2006). We speculated on the putative role of the RA pathway in regulating cell division of supporting cells via $p 27^{k i p}$, based on the fact that induction of the RA pathway upon regeneration (during the first 1-3 h after neomycin exposure) coincides with downregulation of the $p 27^{k i p}$ gene at 1.5 hpt described by Jiang et al. (2014) (Fig. 8A,B). To address this, we checked the effects on $p 27^{k i p}$ expression in regenerating neuromasts under wild-type conditions (heat-shocked and dnRAR negative) and in RA-depleted conditions (heat-shocked and dnRAR positive). Overexpression of dnRAR was induced $2 \mathrm{~h}$ before neomycin treatment because we have observed that it takes $\sim 1.5-2 \mathrm{~h}$ for the dnRAR-GFP protein to be synthetised following heat-shock (data not shown). Strikingly, downregulation of $p 27^{k i p}$ expression was repressed cell-autonomously at 1.5 hpt after dnRAR overexpression (compare Fig. $8 B$ with Fig. $8 C$ ). The degree of $p 27^{k i p}$ expression was directly proportional to the degree of dnRAR overexpression. In the first example (Fig. 8C, top), in which few cells express the dnRAR protein in the neuromast, inhibition of $p 27^{k i p}$ downregulation is only observed in those cells. In a neuromast with higher levels of dnRAR, the lack of repression is enhanced (Fig. $8 C$, bottom).

The activation of the RA pathway also parallels the downregulation of sox2, suggesting that RA could mediate this downregulation as for $p 27^{k i p}$. We found that, under neomycin conditions, sox2 downregulation at $1.5 \mathrm{hpt}$ (compare Fig. $8 D$ with Fig. $8 E$ ) was not observed when RA signaling was impaired (shown in two different examples Fig. $8 F$ ). This suggests that RA signaling, as for $p 27^{k i p}$, is required for the repression of sox 2 expression in supporting cells during hair cell regeneration. Overexpression of dnRAR in non-neomycin-treated embryos did not change the already high levels of sox 2 found in non-neomycin-treated wildtype embryos (data not shown).

Finally, because $f g f 3$ expression is also transiently downregulated at $1.5 \mathrm{hpt}$ and RA signaling has been shown to interact negatively with FGF pathway during otic patterning (Maier et al., 2014), we also checked $f g f 3$ expression after blocking RA signaling. In contrast to what was observed for sox 2 or $p 27^{k i p}$, we could not detect any change on $f g f 3$ expression at $1.5 \mathrm{hpt}$ after dnRAR overexpression, suggesting that the downregulation of $f g f 3$ expression during regeneration is not mediated by the enhanced activity of the RA pathway (Fig. $8 G-I$ ).

We then checked whether, instead of RA regulating FGF signaling, FGF3 could regulate the RA pathway during regeneration, and low levels of $f g f 3$ were required for the activation of the RA pathway. Therefore, we decided to artificially maintain high lev- 


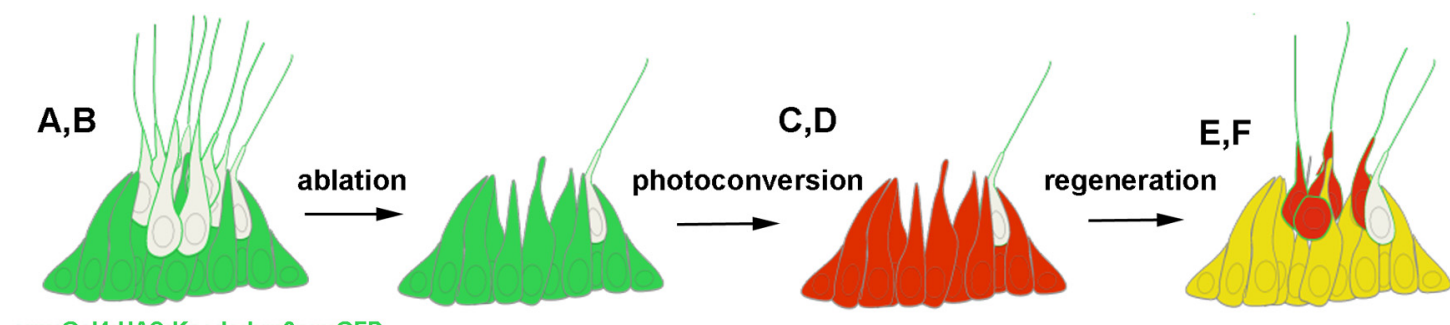

erm:Gal4;UAS:Kaede;brn3c:mGFP

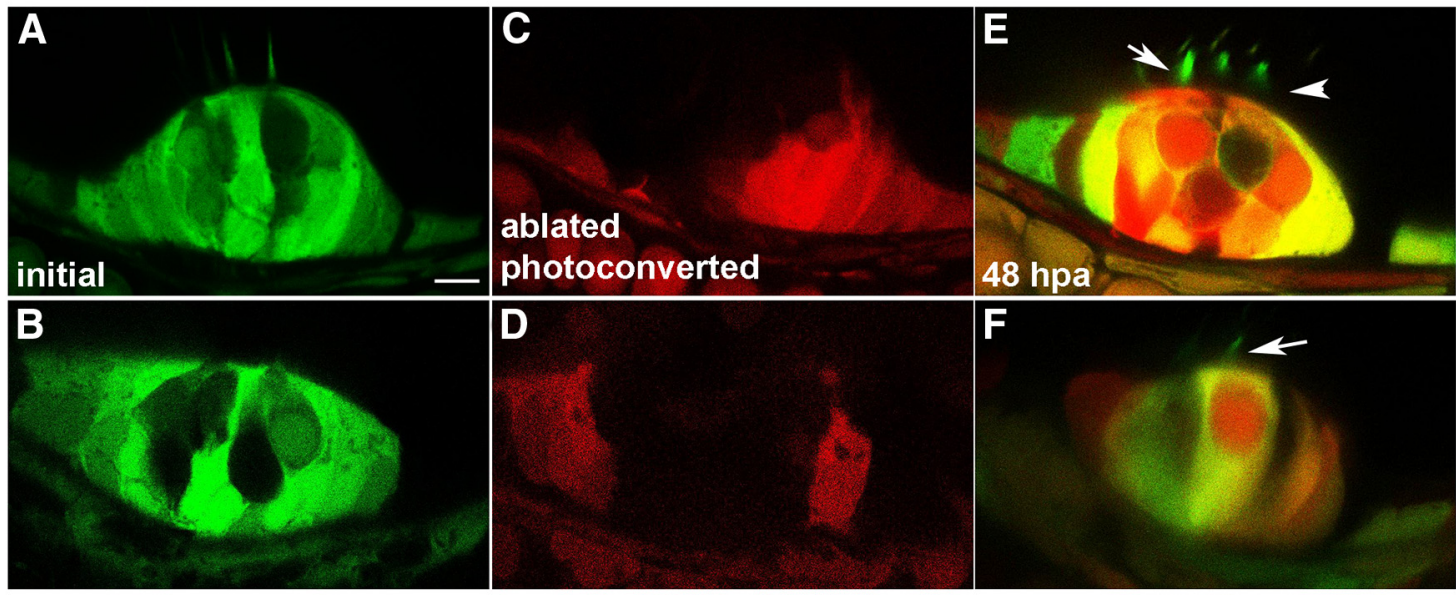

G
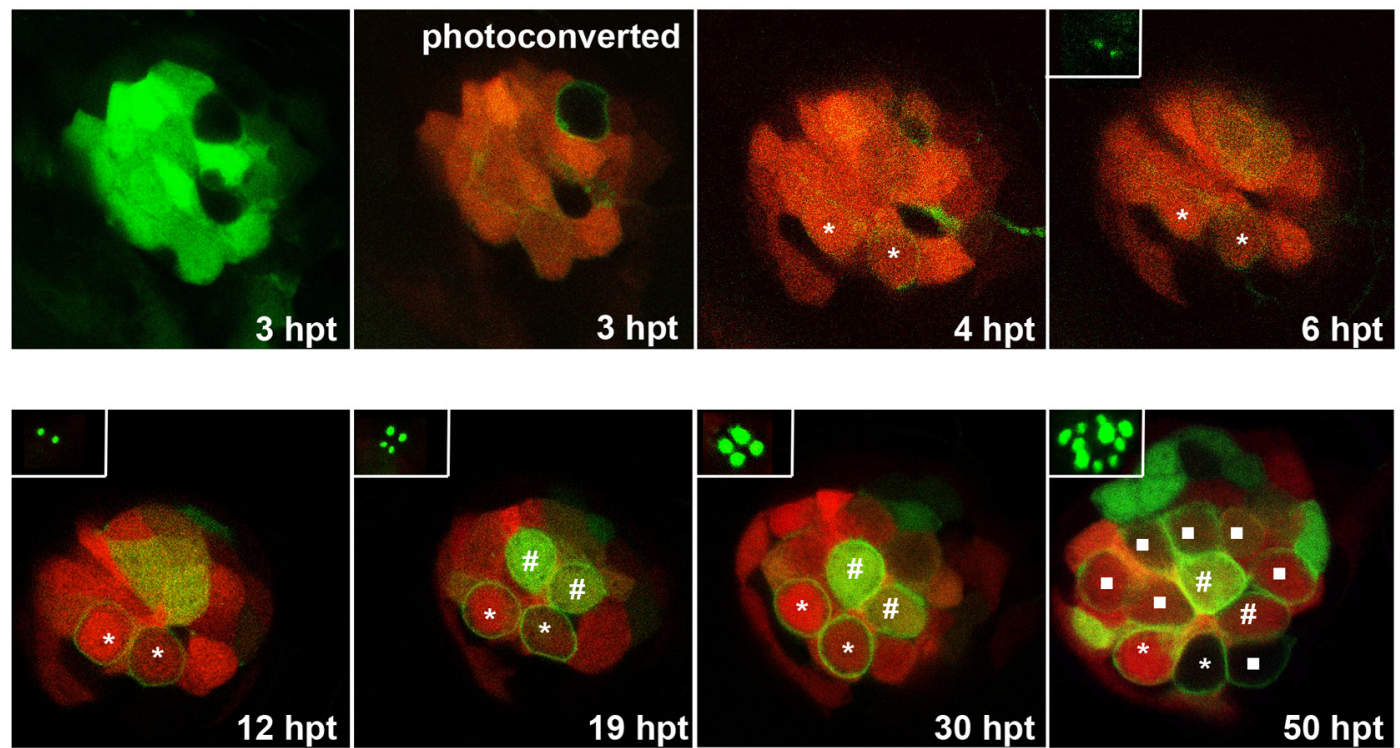

Figure 5. Regenerated hair cells derive from FGF-active supporting cells. $A-F$, Genetic cell-lineage tracing of regenerated hair cells of the lateral crista. $A, B$, Two examples of a transgenic line expressing Kaede protein in supporting cells tg(erm:gal4;UAS:kaede) crossed with $\operatorname{tg}($ brn3c:mGFP). C, D, After hair cell laser ablation, Kaede was photoconverted to red, and hair cell regeneration was analyzed after $48 \mathrm{hpa}$. $\boldsymbol{E}, \boldsymbol{F}$, New hair cells were observed with red cytoplasmic signal and membrane GFP staining, indicating their supporting cell origin (arrows), whereas membrane GFP staining alone identifies hair cells survived to the laser ablation (arrowhead). G, Time-lapse of a regenerating neuromast. The 4.5-d-old tg(erm:gal4;UAS:kaede;brn3c:mGFP) larvae were treated with neomycin, and Kaede was photoconverted at $3 \mathrm{hpt}$. Scale bar: $A, 10 \mu \mathrm{m}$.

els of FGF3 after neomycin treatment by using the $\operatorname{tg}($ hsp 70 :fgf3) transgenic line. We found that, upon FGF3 overexpression, aldh1a3 is still activated at $3 \mathrm{hpt}$ and no ectopic expression of aldh1a3 is visible (Fig. $8 \mathrm{~J}-\mathrm{L}$ ), suggesting that FGF and RA pathways do not cross-regulate each other.

Together, our data strongly support a role of the RA pathway in repressing $p 27^{k i p}$ and sox2 gene transcription under regenerating conditions. Regulation of $p 27^{k i p}$ by RA activity is in agreement with our previous findings that RA inhibition impairs S-phase entry.

\section{Discussion}

In this paper, we describe, for the first time, the role of RA in hair cell regeneration in an intact animal. Our data suggest that the rapid burst of RA signaling in supporting cells of the zebrafish inner ear and lateral line is key for its ability to allow supporting cell to divide. We show that RA represses $p 27^{k i p}$ and sox2, two key genes in hair cell development. RA pathway is therefore required for the generation of new hair cells and to reconstitute the damaged sensory organ. 

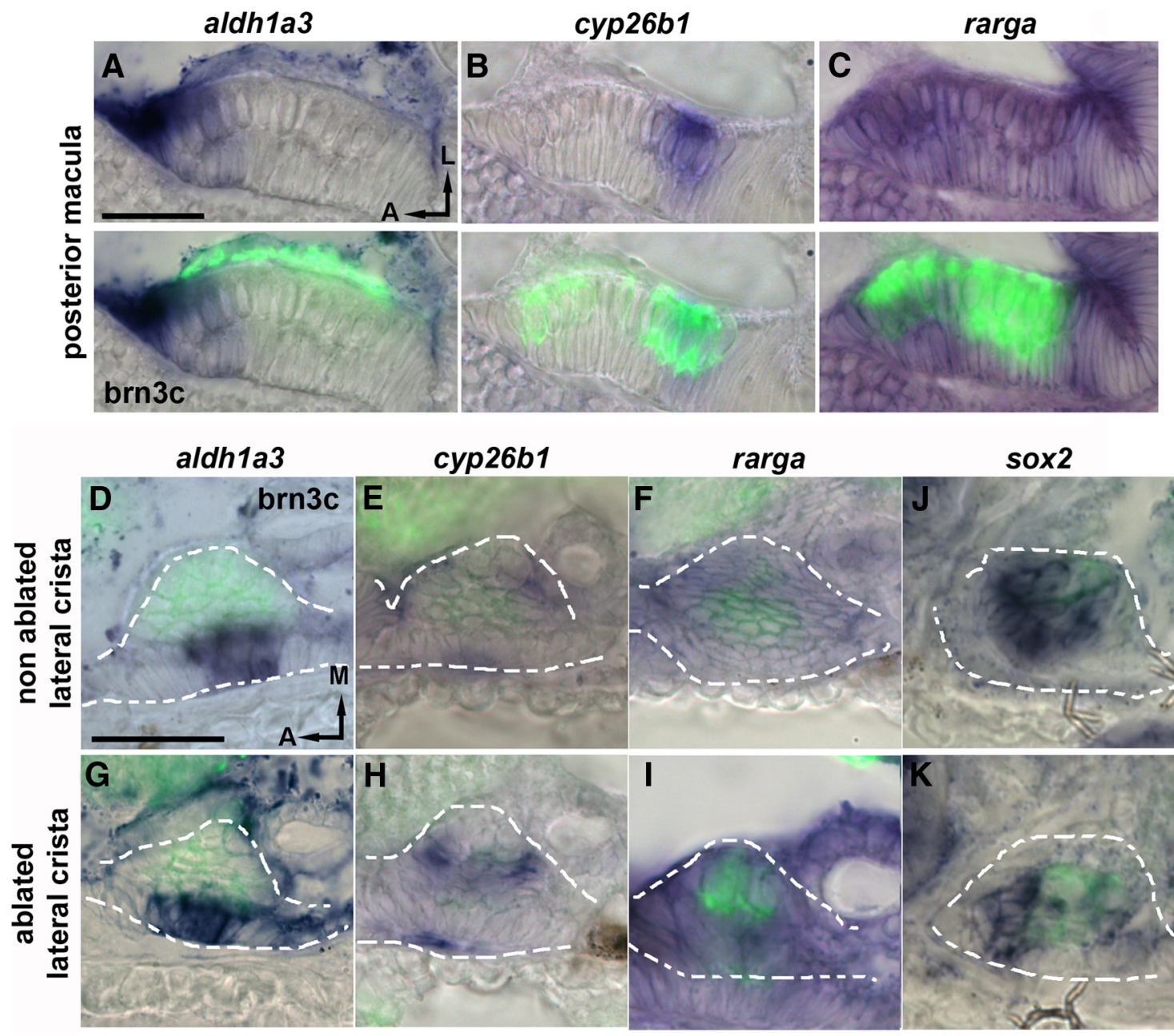

Figure 6. The RA pathway is induced shortly after hair cell loss in the inner ear. $\boldsymbol{A}-\boldsymbol{C}$, Coronal sections of the posterior macula show expression patterns of aldh $1 a 3(\boldsymbol{A})$, cyp26b1 (B), and rarga $(\boldsymbol{C})$ in the inner ear of 4.5-d-old larvae. aldh1a3 is expressed specifically in the anterior domain of the posterior macula, whereas cyp26b1 is expressed in the posterior domain. The rarga receptor is strongly expressed throughout the sensory patch. $\boldsymbol{D}-\boldsymbol{K}$, Coronal sections of the lateral crista. aldh1a3 is expressed in the lateral domain (D), low expression of cyp26b1 is found in the medial domain in wild-type larvae $(\boldsymbol{E})$, and rarga is expressed throughout the crista $(\boldsymbol{F})$. Expression of aldh 1a3, cyp26b1, and rarga is induced at $24 \mathrm{hpa}$ in the lateral crista (G-I), whereas sox2 is downregulated at $4 \mathrm{hpa}(\boldsymbol{J}, \boldsymbol{K})$. In situ hybridization was performed in $\operatorname{tg}($ brn3c:mGFP) larvae, and hair cells are immunolabeled in green. Scale bars: $\boldsymbol{A}, \boldsymbol{D}, 20 \mu \mathrm{m}$.

RA signaling is active in the inner ear during development and has different functions. Before otic vesicle stage, RA synthetized by Raldh 2 next to the otic placode affects early otic placode commitment and patterning (Hans and Westerfield, 2007; Bok et al., 2011; Radosevic et al., 2011). Later, another synthetizing enzyme, Raldh3 (aldh1a3 in zebrafish), is expressed within the otic vesicle and regulates inner ear morphogenesis, and neuronal and sensory differentiation (Choo et al., 1998; Romand et al., 2002; Thompson et al., 2003; Maier and Whitfield, 2014). Of particular interest for the present work, increased levels of RA applied exogenously could trigger ectopic differentiation of hair cells in vitro and in vivo in embryonic otic tissue (Represa et al., 1990; Kelley et al., 1993; León et al., 1995). Kelley et al. (1993) postulated that RA acts on sensory progenitors before they commit to either hair cells or supporting cells because both cell types increased their numbers upon addition of RA. Along this line, recent transcriptomic work suggests a gradient of RA involved in hair cell differentiation along the proximodistal axis of the cochlea (Thiede et al., 2014).

Despite the well-known role of RA signaling in regeneration in the limb, heart, and eye (Niazi and Saxena, 1978; Maden, 1982; Tsonis et al., 2000; Stinchcombe and Maden, 2008; Kikuchi et al.,
2011; Gudas, 2012), its role in inner ear regeneration has little been studied. To date, only one study, in which exogenous RA was applied to newborn organ of Corti tissue, indicated that RA favored hair cell regeneration (Lefebvre et al., 1993). Here, we unveil that the RA pathway is required for hair cell regeneration in the zebrafish inner ear and lateral line and that the RA pathway is rapidly induced upon hair cell damage in both sensory organs. In the inner ear, expression of aldh1a3, rarga, and cyp26b1 is enhanced at $24 \mathrm{hpa}$, whereas in the lateral line, aldh1a3, cyp26c1, cyp26a1, and rargab are transcriptionally activated by $1.5-3 \mathrm{hpt}$. Liang et al. (2012) identified the socs 3 pathway as the first signaling pathway induced upon damage, transcribed at $0 \mathrm{~h}$ after acoustic damage in the inner ear, and returning to normal levels by $24 \mathrm{~h}$. Thus, one possible scenario is that the RA pathway is activated by this cytokine signaling regulator. Other well-known signaling pathways, such as the Notch, Wnt, and FGF pathways, also regulate hair cell regeneration in birds and fish (Lindsell et al., 1996; Lanford et al., 1999; Stone and Rubel, 1999; Ma et al., 2008; Daudet et al., 2009; Millimaki et al., 2010; Wibowo et al., 2011; Mizutari et al., 2013). Temporal mapping of the activation of these pathways in the regenerating lateral line (Jiang et al., 2014) indicate that Notch components are downregulated rap- 


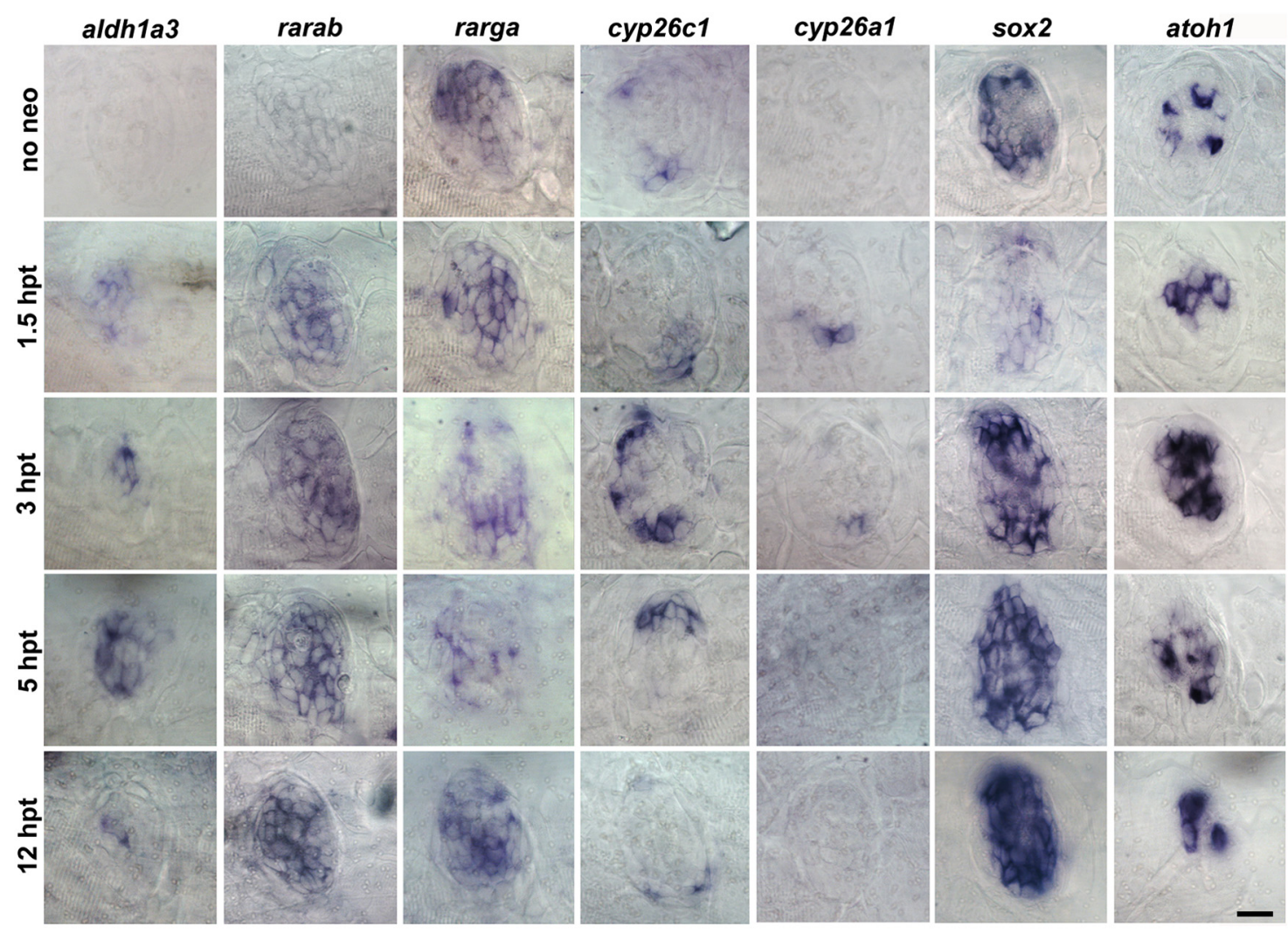

Figure 7. In the lateral line, RA pathway is already induced at $1.5 \mathrm{hpt}$. Expression pattern of components of the RA pathway detected by in situ hybridization in resting state and at various time points during regeneration. In regenerating neuromasts, expression of aldh $1 a 3$, rarab, rarga, and cyp26a1 was upregulated at $1.5 \mathrm{hpt}$, whereas cyp26c1 was upregulated at $3 \mathrm{hpt.}$ sox 2 and atoh $1 a$ were downregulated and upregulated at $1.5 \mathrm{hpt}$, respectively. After transient downregulation of sox 2 at $1.5 \mathrm{hpt}$, expression is rapidly recovered by $3 \mathrm{hpt}$. Scale bar, $10 \mu \mathrm{m}$.

idly after hair cell death, whereas the Wnt pathway is active by 12 hpt. It has been suggested that downregulation of Notch in the center of the neuromast, non-cell-autonomously activates Wnt in the dorsoventral poles where supporting cells divide in a proliferative, expanding manner (Romero-Carvajal et al., 2015). The nature of this signal is unknown, but RA could fit with this role for several reasons: (1) aldh1a3 expression is induced concomitant with Notch downregulation and before Wnt signaling activation; (2) cyp26s expressions are detected in the poles of the neuromast; and (3) RA pathway regulates supporting cell proliferation. In line with this, RA signaling enhances hematopoietic stem cell properties upstream of Wnt during development (Chanda et al., 2013). A possible gradient of RA activity from the center to the outside in the neuromast might be regulating supporting cell proliferation during regeneration. Also worth mentioning, cyp26a1 is induced in few regenerating neuromasts and, when it does so, expression lights up in two adjacent cells. Whether these two cyp26a1-expressing cells are a specific subset of supporting cells with stem cell characteristics, as suggested recently (Cruz et al., 2015), or labels supporting cells in a particular phase of the cell cycle remains to be characterized.

One of the roles of the RA pathway is to promote supporting cell proliferation during regeneration, although other mechanisms of action on hair cell production are plausible. We focused on the cell cycle inhibitor $p 27^{k i p}$ as a possible downstream mediator of RA activity, finding that the RA pathway represses $p 27^{k i p}$ transcription cell-autonomously after hair cell loss, most probably leading to cell cycle reactivation by supporting cells. While the RA pathway has previously been reported to have a role in inducing cell proliferation in the regenerating heart and limbs (Kikuchi et al., 2011; Blum and Begemann, 2012), our data indicate a putative molecular mechanism through which the RA pathway might impinge on cell proliferation, and, for the first time, links this signaling pathway to the cell cycle inhibitor. It is noteworthy that the regulation of $p 27^{k i p}$ by RA might also occur during hair cell development because a gradient in RA signaling has recently been shown to regulate differentiation of chick basilar papilla, and $p 27^{k i p}$ transcription is also regulated in a gradient (Chen and Segil, 1999; Thiede et al., 2014). In neuromasts, it has recently been shown that increased levels of NICD upregulate $p 27^{k i p}$ (Romero-Carvajal et al., 2015); therefore, an interesting scenario would be that both pathways converge on the regulation of cell proliferation of supporting cells via $p 27^{k i p}$, either in parallel or synergistically.

Together with $p 27^{k i p}$, the RA pathway also inhibits sox2 expression during hair cell regeneration. Sox2, an essential gene for sensory development, is expressed in sensory progenitors (Neves et al., 2007, 2012). Sox2 and Atoh1 display a mutual antagonistic interaction during hair cell development, being Sox 2 regulated by Notch (Dabdoub et al., 2008; Millimaki et al., 2010). We observe a transient downregulation of sox2, both in regenerating lateral crista and neuromast, in the latter regulated by RA pathway. However, the exact meaning of this downregulation is unclear because there are high levels instead of low levels of sox2, which promote regeneration (Millimaki et al., 2010). Thus, the transient downregulation could be reflecting the inhibition of Notch signaling during regeneration or could be necessary for the transcriptional changes in the supporting cells leading to the activation of atoh1 expression. Further analysis in this direction should address whether transient sox 2 downregulation is fundamental 

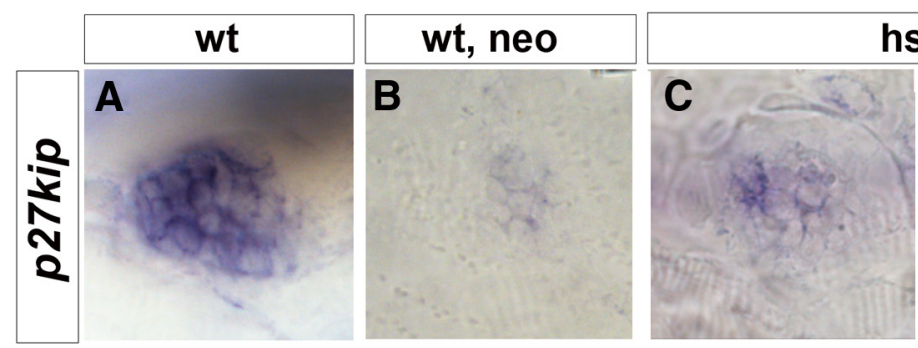

hs dnRAR, neo
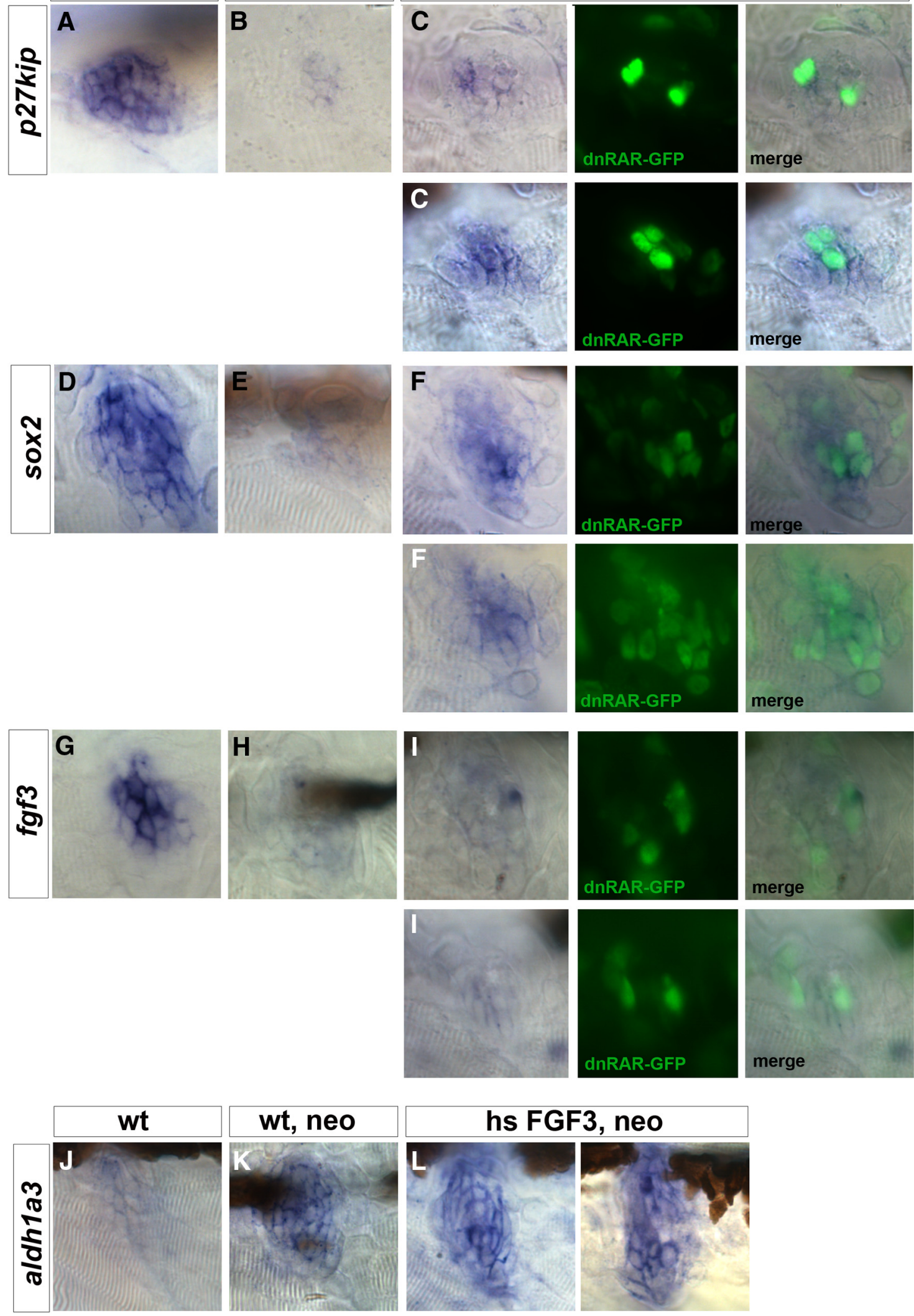

Figure 8. RAR represses $p 27^{\text {kip }}$ and sox 2 during hair cell regeneration but has no effect on fgf3. $A-C, p 27^{k i p}$ is expressed in the supporting cells of neuromasts under wild-type conditions ( $A$ ), but it is strongly downregulated 1.5 hafter hair cell damage $(\boldsymbol{B})$, allowing supporting cells to reenter the cell cycle. $\boldsymbol{C}$, Two representative neuromasts showing that the dnRAR-expressing cells are unable to downregulate $22^{\text {kip }}$ transcription. $\boldsymbol{D}-\boldsymbol{F}$, sox 2 is expressed in the supporting cells of a neuromast in a 4.5 dpf larva under resting conditions $(\boldsymbol{D})$ but downregulated $1.5 \mathrm{~h}$ after neomycin treatment $(\boldsymbol{E})$. $\boldsymbol{F}$, Two representative examples of neuromasts overexpressing dnRAR show inhibition of sox2 downregulation. $\mathbf{G}-\boldsymbol{I}, \mathrm{fgf} 3$ is normally expressed in resting conditions $(\boldsymbol{G})$, and it is repressed $1.5 \mathrm{~h}$ after neomycin $(\boldsymbol{H}) . \boldsymbol{I}, \mathbf{O v e r e x p r e s s i o n ~ o f ~ d n R A R ~}$ does not alter the fgf 3 downregulation after cell damage. $J-L$, Similarly, overexpression of FGF3 does not affect aldh $1 a 3$ expression in regenerating neuromasts 3 hpt. 
and whether it also takes place in other organisms during hair cell regeneration.

During otic vesicle patterning, aldh1a3 expression depends positively on FGF3 signaling, whereas RA downregulate FGF activity (Maier et al., 2014). However, when we checked for a possible interaction during hair cell regeneration, we did not find evidence for a cross-regulation of both pathways, indicative that in this case the interactions during hair cell regeneration do not fully recapitulate development networks.

Although RA signaling has mostly been associated with hair cell differentiation, in this paper we highlight a novel role for RA during regeneration, in which transcriptional changes in supporting cells lead to the initiation of cell proliferation. Recently, RA has been proposed to have a role in facilitating reprogramming of MEF cells into iPS cells when present in low concentrations (Wang et al., 2011; Yang et al., 2015), compared with its classical differentiation role at high concentrations. However, another role of the RA pathway in hair cell differentiation during regeneration or in transdifferentiation of supporting cells is still possible. Transdifferentiation has been accounted as the main mechanism involved in the laser-ablated regenerating zebrafish larva macula (Millimaki et al., 2010), whereas saccule after acoustic trauma and neomycin-treated lateral line regenerate hair cells by the activation of cell proliferation (Harris et al., 2003; Liang et al., 2012). Here, we also find high numbers of proliferating supporting cells after laser ablation of lateral crista, suggesting that this sensory organ regenerates following similar mechanisms as neuromast. In addition, RA pathway is required in both systems, albeit they show some differences on the activated genes of the RA pathway and the kinetics of hair cell regeneration. In the lateral line, several works indicate that transdifferentiation is negligible (López-Schier and Hudspeth, 2006; Ma et al., 2008; Mackenzie and Raible, 2012; Romero-Carvajal et al., 2015), but time-lapse imaging of regeneration in the inner ear is needed to elucidate the exact contribution of transdifferentiation events in zebrafish (as it happens in chick) (Adler and Raphael, 1996). Together, our results on RA signaling during regeneration might be useful to further understand the molecular mechanisms underlying nonmammalian vertebrate hair cell regeneration and at longer term could be a potential therapeutic agent for treating hearing loss.

\section{References}

Adler HJ, Raphael Y (1996) New hair cells arise from supporting cell conversion in the acoustically damaged chick inner ear. Neurosci Lett 205: 17-20. CrossRef Medline

Blum N, Begemann G (2012) Retinoic acid signaling controls the formation, proliferation and survival of the blastema during adult zebrafish fin regeneration. Development 139:107-116. CrossRef Medline

Bok J, Raft S, Kong KA, Koo SK, Dräger UC, Wu DK (2011) Transient retinoic acid signalling confers anterior-posterior polarity to the inner ear. Proc Natl Acad Sci U S A 108:161-166. CrossRef Medline

Cañestro C, Catchen JM, Rodríguez-Mari A, Yokoi H, Postlethwait JH (2009) Consequences of lineage-specific gene loss on functional evolution of surviving paralogs: ALDH1A and retinoic acid signaling in vertebrate genomes. PLoS Genet 5:e1000496. CrossRef Medline

Chanda B, Ditadi A, Iscove NN, Keller G (2013) Retinoic acid signaling is essential for embryonic hematopoietic stem cell development. Cell 155: 215-227. CrossRef Medline

Chapman SC, Cai Q, Bleyl SB, Schoenwolf GC (2006) Restricted expression of Fgf16 within the developing chick inner ear. Dev Dyn 235:2276-2281. CrossRef Medline

Chen P, Segil N (1999) p27(Kip1) links cell proliferation to morphogenesis in the developing organ of Corti. Development 126:1581-1590. Medline

Choo D, Sanne JL, Wu DK (1998) The differential sensitivities of inner ear structures to retinoic acid during development. Dev Biol 204:136-150. CrossRef Medline
Corwin JT, Cotanche DA (1988) Regeneration of sensory hair cells after acoustic trauma. Science 240:1772-1774. CrossRef Medline

Cruz IA, Kappedal R, Mackenzie SM, Hailey DW, Hoffman TL, Schilling TF, Raible DW (2015) Robust regeneration of adult zebrafish lateral line hair cells reflects continued precursor pool maintenance. Dev Biol 402: 229-238. CrossRef Medline

Dabdoub A, Puligilla C, Jones JM, Fritzsch B, Cheah KS, Pevny LH, Kelley MW (2008) Sox2 signaling in prosensory domain specification and subsequent hair cell differentiation in the developing cochlea. Proc Natl Acad Sci U S A 105:18396-18401. CrossRef Medline

Damm K, Heyman RA, Umesono K, Evans RM (1993) Functional inhibition of retinoic acid response by dominant negative retinoic acid receptor mutants. Proc Natl Acad Sci U S A 90:2989-2993. CrossRef Medline

Daudet N, Gibson R, Shang J, Bernard A, Lewis J, Stone J (2009) Notch regulation of progenitor cell behavior in quiescent and regenerating auditory epithelium of mature birds. Dev Biol 326:86-100. CrossRef Medline

Doetzlhofer A, Basch ML, Ohyama T, Gessler M, Groves AK, Segil N (2009) Hey2 regulation by FGF provides a Notch-independent mechanism for maintaining pillar cell fate in the organ of Corti. Dev Cell 16:58-69. CrossRef Medline

Dupé V, Lumsden A (2001) Hindbrain patterning involves graded responses to retinoic acid signalling. Development 128:2199-2208. Medline

Esain V, Postlethwait JH, Charnay P, Ghislain J (2010) FGF-receptor signalling controls neural cell diversity in the zebrafish hindbrain by regulating olig2 and sox9. Development 137:33-42. CrossRef Medline

Geling A, Itoh M, Tallafuss A, Chapouton P, Tannhäuser B, Kuwada JY, Chitnis AB, Bally-Cuif L (2003) bHLH transcription factor Her5 links patterning to regional inhibition of neurogenesis at the midbrainhindbrain boundary. Development 130:1591-1604. CrossRef Medline

Gubbels SP, Woessner DW, Mitchell JC, Ricci AJ, Brigande JV (2008) Functional auditory hair cells produced in the mammalian cochlea by in utero gene transfer. Nature 455:537-541. CrossRef Medline

Gudas LJ (2012) Emerging roles for retinoids in regeneration and differentiation in normal and disease states. Biochim Biophys Acta 1821:213-221. CrossRef Medline

Haas P, Gilmour D (2006) Chemokine signaling mediates self-organizing tissue migration in the zebrafish lateral line. Dev Cell 10:673-680. CrossRef Medline

Hans S, Westerfield M (2007) Changes in retinoic acid signaling alter otic patterning. Development 134:2449-2458. CrossRef Medline

Harris JA, Cheng AG, Cunningham LL, MacDonald G, Raible DW, Rubel EW (2003) Neomycin-induced hair cell death and rapid regeneration in the lateral line of zebrafish (Danio rerio). J Assoc Res Otolaryngol 4:219-234. CrossRef Medline

Hawkins RD, Bashiardes S, Powder KE, Sajan SA, Bhonagiri V, Alvarado DM, Speck J, Warchol ME, Lovett M (2007) Large scale gene expression profiles of regenerating inner ear sensory epithelia. PLoS One 2:e525. CrossRef Medline

Hayashi T, Cunningham D, Bermingham-McDonogh O (2007) Loss of Fgfr3 leads to excess hair cell development in the mouse organ of Corti. Dev Dyn 236:525-533. CrossRef Medline

Hayashi T, Ray CA, Bermingham-McDonogh O (2008) Fgf20 is required for sensory epithelial specification in the developing cochlea. J Neurosci 28:5991-5999. CrossRef Medline

Hernandez PP, Moreno V, Olivari FA, Allende ML (2006) Sub-lethal concentrations of waterborne copper are toxic to lateral line neuromasts in zebrafish (Danio rerio). Hear Res 213:1-10. CrossRef Medline

Izumikawa M, Minoda R, Kawamoto K, Abrashkin KA, Swiderski DL, Dolan DF, Brough DE, Raphael Y (2005) Auditory hair cell replacement and hearing improvement by Atohl gene therapy in deaf mammals. Nat Med 11:271-276. CrossRef Medline

Jacques BE, Dabdoub A, Kelley MW (2012) Fgf signaling regulates development and transdifferentiation of hair cells and supporting cells in the basilar papilla. Hear Res 289:27-39. CrossRef Medline

Jiang L, Romero-Carvajal A, Haug JS, Seidel CW, Piotrowski T (2014) Gene-expression analysis of hair cell regeneration in the zebrafish lateral line. Proc Natl Acad Sci U S A 111:E1383-E1392. CrossRef Medline

Kawamoto K, Ishimoto S, Minoda R, Brough DE, Raphael Y (2003) Math1 gene transfer generates new cochlear hair cells in mature guinea pigs in vivo. J Neurosci 23:4395-4400. Medline

Kelley MW, Xu XM, Wagner MA, Warchol ME, Corwin JT (1993) The 
developing organ of Corti contains retinoic acid and forms supernumerary hair cells in response to exogenous retinoic acid in culture. Development 119:1041-1053. Medline

Kikuchi K, Holdway JE, Major RJ, Blum N, Dahn RD, Begemann G, Poss KD (2011) Retinoic acid production by endocardium and epicardium is an injury response essential for zebrafish heart regeneration. Dev Cell 20: 397-404. CrossRef Medline

Kimmel CB, Ballard WW, Kimmel SR, Ullmann B, Schilling TF (1995) Stages of embryonic development of the zebrafish. Dev Dyn 203:253-310. CrossRef Medline

Lanford PJ, Lan Y, Jiang R, Lindsell C, Weinmaster G, Gridley T, Kelley MW (1999) Notch signalling pathway mediates hair cell development in mammalian cochlea. Nat Genet 21:289-292. CrossRef Medline

Lecaudey V, Cakan-Akdogan G, Norton WH, Gilmour D (2008) Dynamic Fgf signaling couples morphogenesis and migration in the zebrafish lateral line primordium. Development 135:2695-2705. CrossRef Medline

Lefebvre PP, Malgrange B, Staecker H, Moonen G, Van de Water TR (1993) Retinoic acid stimulates regeneration of mammalian auditory hair cells. Science 260:692-695. CrossRef Medline

León Y, Sanchez JA, Miner C, Ariza-McNaughton L, Represa JJ, Giraldez F (1995) Developmental regulation of Fos-protein during proliferative growth of the otic vesicle and its relation to differentiation induced by retinoic acid. Dev Biol 167:75-86. CrossRef Medline

Liang J, Wang D, Renaud G, Wolfsberg TG, Wilson AF, Burgess SM (2012) The stat3/socs3a pathway is a key regulator of hair cell regeneration in zebrafish [corrected]. J Neurosci 32:10662-10673. CrossRef Medline

Li W, Wu J, Yang J, Sun S, Chai R, Chen ZY, Li H (2015) Notch inhibition induces mitotically generated hair cells in mammalian cochleae via activating the Wnt pathway. Proc Natl Acad Sci U S A 112:166-171. CrossRef Medline

Lin V, Golub JS, Nguyen TB, Hume CR, Oesterle EC, Stone JS (2011) Inhibition of Notch activity promotes nonmitotic regeneration of hair cells in the adult mouse utricles. J Neurosci 31:15329-15339. CrossRef Medline

Lindsell CE, Boulter J, diSibio G, Gossler A, Weinmaster G (1996) Expression patterns of Jagged, Delta1, Notch1, Notch2, and Notch3 genes identify ligand-receptor pairs that may function in neural development. Mol Cell Neurosci 8:14-27. CrossRef Medline

López-Schier H, Hudspeth AJ (2006) A two-step mechanism underlies the planar polarization of regenerating sensory hair cells. Proc Natl Acad Sci U S A 103:18615-18620. CrossRef Medline

Ma EY, Rubel EW, Raible DW (2008) Notch signaling regulates the extent of hair cell regeneration in the zebrafish lateral line. J Neurosci 28:22612273. CrossRef Medline

Mackenzie SM, Raible DW (2012) Proliferative regeneration of zebrafish lateral line hair cells after different ototoxic insults. PLoS One 7:e47257. CrossRef Medline

Maden M (1982) Vitamin A and pattern formation in the regenerating limb. Nature 295:672-675. CrossRef Medline

Maier EC, Whitfield TT (2014) RA and FGF signalling are required in the zebrafish otic vesicle to pattern and maintain ventral otic identities. PLoS Genet 10:e1004858. CrossRef Medline

März M, Chapouton P, Diotel N, Vaillant C, Hesl B, Takamiya M, Lam CS, Kah O, Bally-Cuif L, Strahle U (2010) Heterogeneity in progenitor cell subtypes in the ventricular zone of the zebrafish adult telencephalon. Glia 58:870-888. CrossRef Medline

Maves L, Jackman W, Kimmel CB (2002) FGF3 and FGF8 mediate a rhombomere 4 signaling activity in the zebrafish hindbrain. Development 129: 3825-3837. Medline

Mey J, McCaffery P, Klemeit M (2001) Sources and sink of retinoic acid in the embryonic chick retina: distribution of aldehyde dehydrogenase activities, CRABP-I, and sites of retinoic acid inactivation. Brain Res Dev Brain Res 127:135-148. CrossRef Medline

Millimaki BB, Sweet EM, Dhason MS, Riley BB (2007) Zebrafish atoh1 genes: classic proneural activity in the inner ear and regulation by Fgf and Notch. Development 134:295-305. CrossRef Medline

Millimaki BB, Sweet EM, Riley BB (2010) Sox2 is required for maintenance and regeneration, but not initial development, of hair cells in the zebrafish inner ear. Dev Biol 338:262-269. CrossRef Medline

Mizutari K, Fujioka M, Hosoya M, Bramhall N, Okano HJ, Okano H, Edge AS (2013) Notch inhibition induces cochlear hair cell regeneration and recovery of hearing after acoustic trauma. Neuron 77:58-69. CrossRef Medline
Monaghan JR, Maden M (2012) Visualization of retinoic acid signaling in transgenic axolotls during limb development and regeneration. Dev Biol 368:63-75. CrossRef Medline

Neves J, Kamaid A, Alsina B, Giraldez F (2007) Differential expression of Sox 2 and Sox 3 in neuronal and sensory progenitors of the developing inner ear of the chick. J Comp Neurol 503:487-500. CrossRef Medline

Neves J, Uchikawa M, Bigas A, Giraldez F (2012) The prosensory function of Sox 2 in the chicken inner ear relies on the direct regulation of Atoh1. PLoS One 7:e30871. CrossRef Medline

Niazi IA, Saxena S (1978) Abnormal hind limb regeneration in tadpoles of the toad, Bufo andersoni, exposed to excess vitamin A. Folia Biol (Krakow) 26:3-8. Medline

Ono K, Kita T, Sato S, O’Neill P, Mak SS, Paschaki M, Ito M, Gotoh N, Kawakami K, Sasai Y, Ladher RK (2014) FGFR1-Frs2/3 signalling maintains sensory progenitors during inner ear hair cell formation. PLoS Genet 10:e1004118. CrossRef Medline

Pickles JO (2001) The expression of fibroblast growth factors and their receptors in the embryonic and neonatal mouse inner ear. Hear Res 155: 54-62. CrossRef Medline

Pirvola U, Spencer-Dene B, Xing-Qun L, Kettunen P, Thesleff I, Fritzsch B, Dickson C, Ylikoski J (2000) FGF/FGFR-2(IIIb) signaling is essential for inner ear morphogenesis. J Neurosci 20:6125-6134. Medline

Pittlik S, Begemann G (2012) New sources of retinoic acid synthesis revealed by live imaging of an Aldh1a2-GFP reporter fusion protein throughout zebrafish development. Dev Dyn 241:1205-1216. CrossRef Medline

Radosevic M, Robert-Moreno A, Coolen M, Bally-Cuif L, Alsina B (2011) Her9 represses neurogenic fate downstream of Tbx1 and retinoic acid signaling in the inner ear. Development 138:397-408. CrossRef Medline

Recher G, Jouralet J, Brombin A, Heuzé A, Mugniery E, Hermel JM, Desnoulez S, Savy T, Herbomel P, Bourrat F, Peyriéras N, Jamen F, Joly JS (2013) Zebrafish midbrain slow-amplifying progenitors exhibit high levels of transcripts for nucleotide and ribosome biogenesis. Development 140:4860-4869. CrossRef Medline

Represa J, Sanchez A, Miner C, Lewis J, Giraldez F (1990) Retinoic acid modulation of the early development of the inner ear is associated with the control of c-fos expression. Development 110:1081-1090. Medline

Romand R, Hashino E, Dollé P, Vonesch JL, Chambon P, Ghyselinck NB (2002) The retinoic acid receptors RARalpha and RARgamma are required for inner ear development. Mech Dev 119:213-223. CrossRef Medline

Romero-Carvajal A, Navajas Acedo J, Jiang L, Kozlovskaja-Gumbrienë A, Alexander R, Li H, Piotrowski T (2015) Regeneration of sensory hair cells requires localized interactions between the Notch and Wnt pathways. Dev Cell 34:267-282. CrossRef Medline

Ryals BM, Rubel EW (1988) Hair cell regeneration after acoustic trauma in adult Coturnix quail. Science 240:1774-1776. CrossRef Medline

Scadding SR, Maden M (1994) Retinoic acid gradients during limb regeneration. Dev Biol 162:608-617. CrossRef Medline

Schindelin J, Arganda-Carreras I, Frise E, Kaynig V, Longair M, Pietzsch T, Preibisch S, Rueden C, Saalfeld S, Schmid B, Tinevez JY, White DJ, Hartenstein V, Eliceiri K, Tomancak P, Cardona A (2012) Fiji: an opensource platform for biological-image analysis. Nat Methods 9:676-682. CrossRef Medline

Shimozono S, Iimura T, Kitaguchi T, Higashijima S, Miyawaki A (2013) Visualization of an endogenous retinoic acid gradient across embryonic development. Nature 496:363-366. CrossRef Medline

Slowik AD, Bermingham-McDonogh O (2013) Hair cell generation by notch inhibition in the adult mammalian cristae. J Assoc Res Otolaryngol 14:813-828. CrossRef Medline

Stinchcombe SV, Maden M (2008) Retinoic acid induced alveolar regeneration: critical differences in strain sensitivity. Am J Respir Cell Mol Biol 38:185-191. CrossRef Medline

Stone JS, Rubel EW (1999) Delta1 expression during avian hair cell regeneration. Development 126:961-973. Medline

Thiede BR, Mann ZF, Chang W, Ku YC, Son YK, Lovett M, Kelley MW, Corwin JT (2014) Retinoic acid signalling regulates the development of tonotopically patterned hair cells in the chicken cochlea. Nat Commun 5:3840. CrossRef Medline

Thisse B, Heyer V, Lux A, Alunni V, Degrave A, Seiliez I, Kirchner J, Parkhill JP, Thisse C (2004) Spatial and temporal expression of the zebrafish 
genome by large-scale in situ hybridization screening. Methods Cell Biol 77:505-519. CrossRef Medline

Thompson DL, Gerlach-Bank LM, Barald KF, Koenig RJ (2003) Retinoic acid repression of bone morphogenetic protein 4 in inner ear development. Mol Cell Biol 23:2277-2286. CrossRef Medline

Tsonis PA, Trombley MT, Rowland T, Chandraratna RA, del Rio-Tsonis K (2000) Role of retinoic acid in lens regeneration. Dev Dyn 219:588-593. CrossRef Medline

Wang W, Yang J, Liu H, Lu D, Chen X, Zenonos Z, Campos LS, Rad R, Guo G, Zhang S, Bradley A, Liu P (2011) Rapid and efficient reprogramming of somatic cells to induced pluripotent stem cells by retinoic acid receptor gamma and liver receptor homolog 1. Proc Natl Acad Sci U S A 108: 18283-18288. CrossRef Medline

White PM, Doetzlhofer A, Lee YS, Groves AK, Segil N (2006) Mammalian cochlear supporting cells can divide and trans-differentiate into hair cells. Nature 441:984-987. CrossRef Medline

White RJ, Nie Q, Lander AD, Schilling TF (2007) Complex regulation of cyp26al creates a robust retinoic acid gradient in the zebrafish embryo. PLoS Biol 5:e304. CrossRef Medline

Wibowo I, Pinto-Teixeira F, Satou C, Higashijima S, López-Schier H (2011) Compartmentalized Notch signaling sustains epithelial mirror symmetry. Development 138:1143-1152. CrossRef Medline

Williams JA, Holder N (2000) Cell turnover in neuromasts of zebrafish larvae. Hear Res 143:171-181. CrossRef Medline

Wong LF, Yip PK, Battaglia A, Grist J, Corcoran J, Maden M, Azzouz M, Kingsman SM, Kingsman AJ, Mazarakis ND, McMahon SB (2006) Retinoic acid receptor beta2 promotes functional regeneration of sensory axons in the spinal cord. Nat Neurosci 9:243-250. CrossRef Medline

Xiao T, Roeser T, Staub W, Baier H (2005) A GFP-based genetic screen reveals mutations that disrupt the architecture of the zebrafish retinotectal projection. Development 132:2955-2967. CrossRef Medline

Yang J, Wang W, Ooi J, Campos LS, Lu L, Liu P (2015) Signalling through retinoic acid receptors is required for reprogramming of both MEFs and EpiSCs to iPSCs. Stem Cells 33:1390-1404. CrossRef Medline 